UC-NRLF

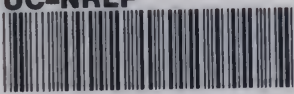

के $36 \quad 383$

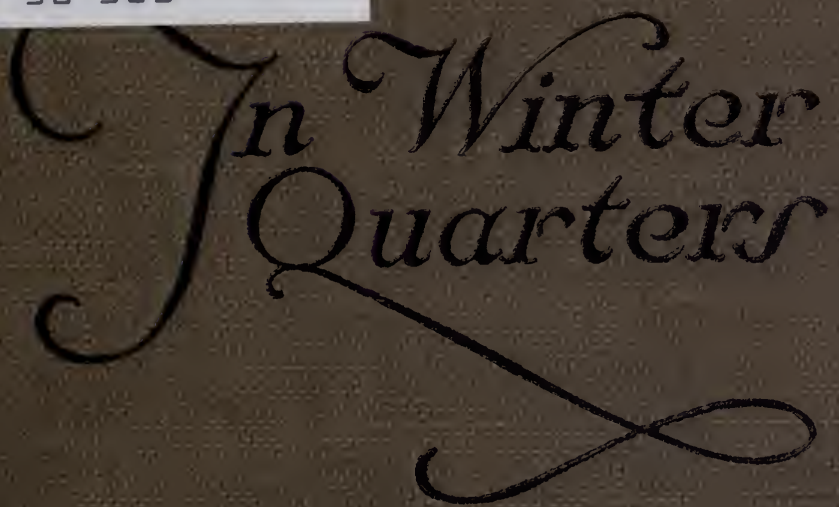

ALVIN HOWARD SANDERS 


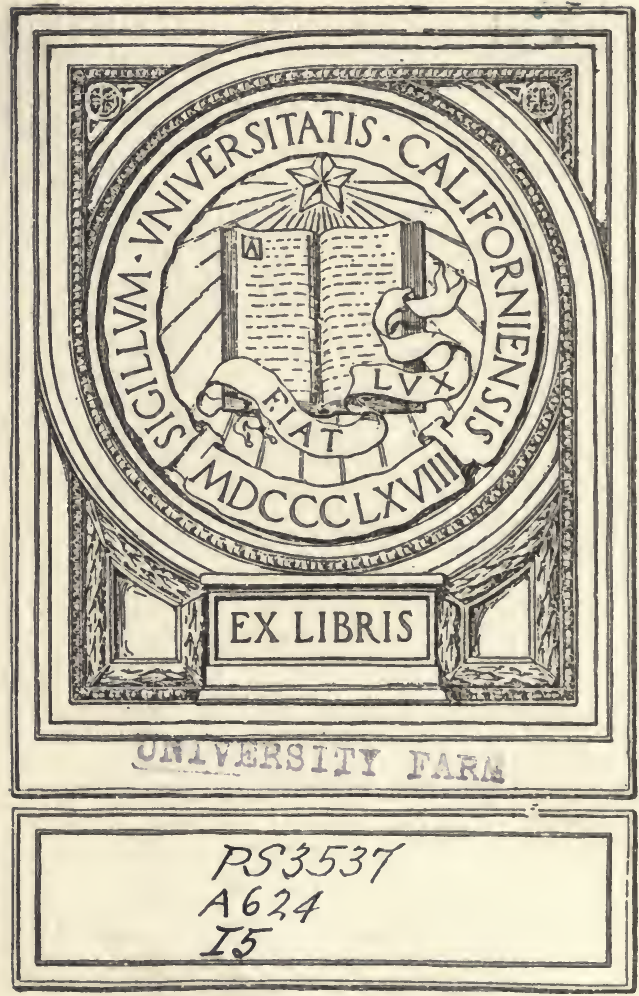


UNTVERSITY OF CALIFORNIA LIBRARY 

IN WINTER QUARTERS 



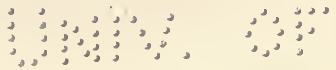

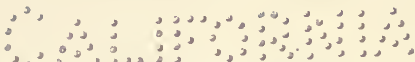


$\because \vdots \because \quad \because \because \vdots \vdots \because \vdots \vdots \vdots$

$\therefore \vdots \vdots \because \because \because \because \cdots \vdots \vdots \vdots \therefore \cdots \cdots$

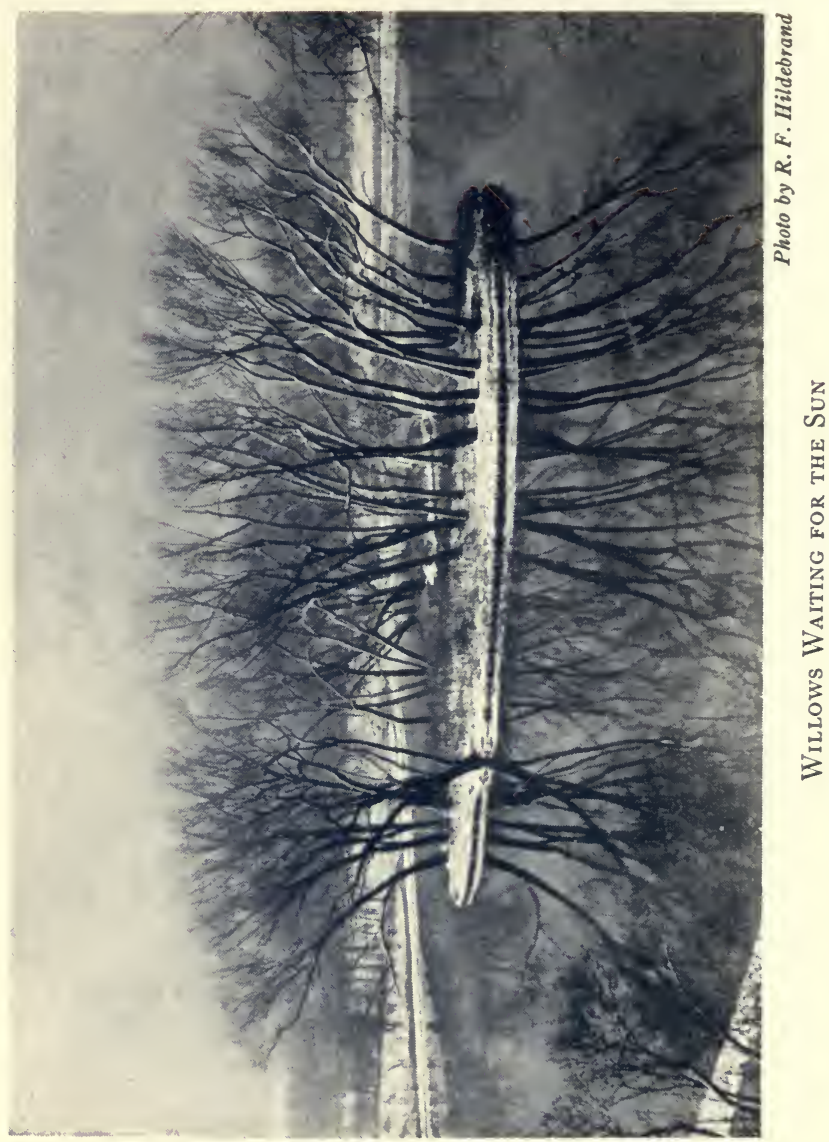




\title{
In Winter Quarters
}

\section{From Dumbiedykes}

To Town and Back Again

\author{
By
}

Alvin Howard Sanders

Editor "The Breeder's Gazette"

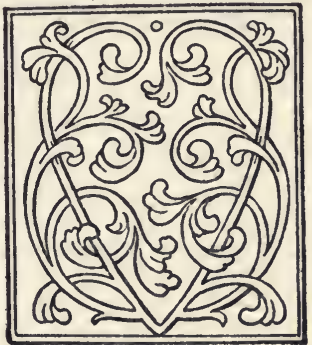

Chicago

Breeder's Gazette Print

1920 


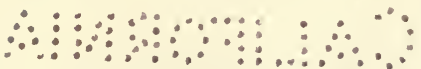

Copyright, 1920

Sanders Publishing Company

All Rights Reserved

\section{UAVEREIJY SAFH}


Books by the Same Author

The Black Swans.

The Road to Dumbiedykes. At the Sign of the Stock Yard Inn.

The Story of the Herefords. Shorthorn Cattle.

A History of the Percheron Horse (in collaboration). 



\section{Introductory}

DEPEATED requests from readers of "The Road to Dumbiedykes," and its companion volume, "The Black Swans," have led the writer to attempt the fulfillment of a promise vaguely made in the concluding paragraph of the series of sketches last above mentioned. The two former grew out of vacation days in the out-of-doors. From "Dumbiedykes" to an apartment house in Lincoln Park West involves a change of base that finds reflection in these pages.

Frost-crystals and "sun-dogs" have splendors not surpassed by the halos of the harvest moon. Still I confess that I prefer to brave the blizzards of the present from inside the library window, and do most of my shoveling these days in the drifts of bygone years. If therefore I deal mainiy with "the snows of yesterday" it will be because an arm-chair outlook somehow invites reflective retrospection rather than comment on the passing storm.

The Author.

Chicago, January, 1920. 
"The wilderness is near as well as dear to every man. The very uprightness of the pines and maples asserts the ancient rectitude and vigor of Nature. Our lives need the relief of such a background, where the pine flourishes and the jay still screams."-Henry D. Thoreau. 


\section{Contents}

CHAPTER

PAGE

I “Cloudy and Colder" . I

II Rattling the Chains . I7

III Perseus or Pugilist? . 29

IV Seeing Things . . 39

V A Governor's Gift . . 5 I

VI GoIng BAcK . . . 6I

VII When Snows Are Deep 8I VIII Parkways AND WILLOWS • • . • • • 93

IX Behind Iron Bars . . II7

$\mathrm{X}$ Compelling Chords . I4I

XI Eight Bells . . . . I59

XII Speaking of Rocks . . I73

XIII One Way OUt . . . I85

XIV As Ye Hoe so Shall

YE REAP • . . . I99

XV "FAIR AND WARMER" . 2 II 



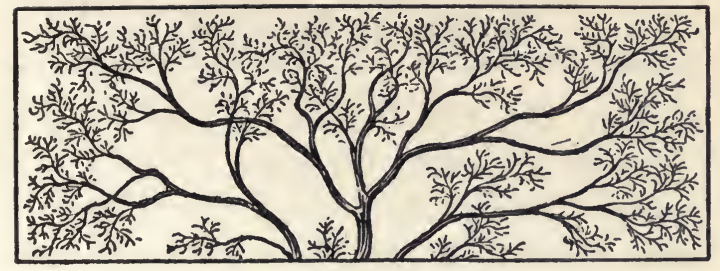

\section{IN WINTER QUARTERS}

\section{I \\ "Cloudy and Colder"}

$A^{S K}$ any well-informed squirrel or $\mathrm{A}_{\text {blue-jay you may chance to meet }}$ in this latitude as you stroll along the edge of a wood on a dull November day, and you will be told that gray skies and cold dark nights are not half so bad as they are sometimes painted, if you understand what they really mean. They know that those old leaves have to come down to make way for next year's crop. They know that the rain that so bedraggled the landscape last week was needed by the fall-sown grain and was delivered in the laboratories of the fields and forests 


\section{In Winter Quarters}

just at the right time to insure the growths you will be expecting in the spring. The jays, in fact, are happiest when there is frost in the air and snow in their beloved thickets. They were busy all day yesterday watching us, at a safe distance, as we were preparing the cottage and the lawn, the flower-beds and the shrubbery for their annual cold-storage experiences.

Wise blue-jays - and few excel their tribe in all-around craftiness-never get on really intimate terms with men or boys. They know better. They are perfectly well aware of the fact that they are under indictment, on various criminal charges, in every community they invade. They are thieves and outlaws. There is no doubt on that point. They are the Robin Hoods of bird-land. They scold and quarrel and steal, and build no nests under your eaves or in your hedge-rows. It is all right of course for us to inveigle old barnyard "Biddy" into our coop, and 
then loot her nest for our own satisfaction, and kill her young that we may feast, but let a blue-jay indulge himself in the delicacies that appeal most to his hearty appetite and our hands go up in horror at the cruel rapacity of his wild untutored nature. Just the same there is a note in his cry I like. It is a challenge to his enemies; the call of the neighboring wild. There is no suggestion of submission; nothing meek or subdued in his attitude. $\mathrm{He}$ is a savage. $\mathrm{He}$ admits it and glories in it. $\mathrm{He}$ is the very incarnation of the sturdy spirit of the northern winter, just as the meadow lark is the tangible embodiment of Maytime joys and happiness. I once thought it good fun to shoot and kill both. Now I had as soon turn the muzzle of the gun upon myself as to bring one of them to earth.

What a bundle of inconsistencies we are anyhow. While I shot no blue-jays on the day of which I speak I did not 


\section{In Winter Quarters}

hesitate to bring certain other forms of life to an abrupt close. A killing frost had already shaken down the barberry leaves that had sheltered brown thrushes and their babies from midsummer suns and prying eyes. The rabbits will profit by this, as they will have snug cover when the snowdrifts come. A pair of friendly burr oaks parted with the foliage that had once been dear to wrens and robins, in an effort at protecting from the rigors now at hand a bed of pansies that have been a perfect riot of black and brown and blue and pink and white and gold week after week all season through. They are discouraged now because of the cold wet storms of recent days, and have evidently made up their minds to give it up for this year, and trust to the trees about them to see them safely through 'til spring. And the trees, observing their plight, have come to their aid. When I went out there the other day-the day of the 
blue-jay frolic in the depths of the grove,-just one wan little purple face was peeping through the thick brown "comforter" the oaks had sent to keep them warm. When I saw this, and recalled how years before a similar lot of plants had gone through the winter underneath just such a covering, and were fine bloomers the ensuing summer, I came near throwing away the big fat Holland bulbs bought to take their place, and giving the pansies their chance for life. But I didn't. I just picked the sole survivor, tucked it into the lapel of my coat, and, like the "rough-neck" I felt myself to be in committing such an apparent sacrilege, spaded the whole lot deeply under the rich black earth, out of which they had so mysteriously elaborated their various winsome personalities, set the tulip tubers in amongst the buried plants, re-covered all with russet leaves held down by a piece of woven-wire netting and a few 


\section{In Winter Quarters}

sticks of fire-wood belonging to the "Black Swans," and left them there; the one to furnish food for future annuals, and the other to prepare our welcome when the sun comes back from his long vacation in the south. Plants, as well as plover and other people, have to take their appointed posts, each in turn, as the zero hour is struck and the Eternal wheel goes round.

Each year we seem to heed less and less the annual autumn call of the city, because you know we have no real home but a bungalow embowered in woodland shades. We love to stay and watch the gold turn into gray, and some day I shall surely wait and watch the gray grow white, for winter is an old, old friend of mine. Nature blows first hot, then cold, while engaged in setting her greatest transformation scenes. It is in the alternate melting and congealing process that she seems to mix her finest colors. 
Only two days ago a warm shower set April in our midst, and deceived the dandelions into blooming. Yesterday a north wind brought dense volumes of cold, wet, low-hanging clouds that poured rain and sleet over a lot of rapidly disappearing beauty. Today it is clear and cold, and forest aisles are filling fast. Only the bluegrass holds its color, and still tries to grow.

Men who know the psychic value, the strange, indefinable, rejuvenating power of forest depths, find the same fine sense of liberty and re-creation in wildwood paths when trees are bare as when all the greenery is there. At such a time there is brought out sometimes in startling fashion the marked individuality of trees, the real personalities of which are more or less disguised when clothed in wigs and gowns. The clinging parasites that flaunt their flowing, modifying lines on noble trunks when suns are hot, fall back, forgotten now, into the dark 


\section{In Winter Quarters}

shadows from whence they sprang. You can get much closer to a tree in winter than in summer. You can no more know a tree when in full regalia than you can judge the carcass of a long-wooled sheep by looking at it before its fleece has been shorn. There are crooks and curves and gnarls and knots and hollow trunks, beloved of bees or birds, which you will never see except when north winds blow. I am speaking now of native growths. Your well-groomed nursery stock is all well enough if you can't get trees any other way. But I know single glorious pines and chestnuts standing on a West Virginia mountain ridge that are worth all the counterfeits I am going to see from my library window this winter in town put together. And in planting, why will so many people persist in trying delicate exotics that cannot possibly do any good? Build your house near native forest trees if you can. If you can't, then use the stock 
that is known to be able to stand your climate and thrive. Why torture a dainty cut-leaved birch or a beautiful beech by asking it to drag out a brief and precarious existence under conditions where it cannot possibly be happy? And so with shrubbery. Draw on the roadside and the tangled woodlots. There will be crab apples and thorns and sumacs, wild grapes and creepers that will respond to care, and laugh at storms and drouths, because they come of an ancestry that has accommodated itself to that which has to be faced each recurring winter and summer. Mark some of these during your winter walks, and maybe in the early spring you can at light expense transform bare or unsightly places into attractive pictures later on.

Meantime the telephone is ringing:

"Hello! This is the office. Will you be in tomorrow?"

"No. I am not yet through closing up the place." 


\section{In Winter Quarters}

"Well, you know we are waiting for that editorial stuff."

"Yes, I know, but I have 300 tulip and crocus bulbs to put in yet, and the water has to be shut off, and the stormwindows put on the cottage, and we are not through chopping wood. You know we have to leave some back-logs ready for use next April when we open up again."

"When will you be in?"

"Next week."

And so we are dragged within the city walls. Thus do we pass inside the gates that swing not open until the sun gets back from Patagonia.

As we turn into Lincoln Park West we are greeted by snow flurries blowing in from off the lake. I suppose it is time we were back in town, and I am thankful for this evidence that winter is here. One season has drifted so imperceptibly into another that I scarcely realized that the day I once so fondly anticipated had at last arrived. I 
hope the ground will be white in the morning.

The first real snowstorm is the best. It transforms instantly a scene of dreariness into a wonderland of pure delight. If great snowfalls occurred as seldom as the eruptions'of Aetna, there would not be Pullmans, Fords and airships enough to transport people across continents to view the matchless beauty of the weeds and woods, the hen roosts, garbage dumps and hovels all glorified by its presence. That which is common is uninteresting. Virtue has to be its own reward; vice holds the first page, and gets the headlines.

Around the margin of the park lagoon next morning there were signs of ice; thin crystals clinging to the halffrozen earth in the indentations of the shore line, sharp as spear points at the tips projected towards the open water, transparent and too fragile for any handling. Such I suppose also was the 


\section{In Winter Quarters}

inconsequential original beginning of the ice sheet, under which this lower end of Lake Michigan once awaited the sun's releasing rays. This sheet extended southward some two or three hundred miles from what is now the site of the city of Chicago, and is supposed to have had a slope of not less than 25 feet per mile towards its distant center in the north. Its thickness therefore over the present site of the Blackstone must have been something more than 6,000 feet-well over a mile; and if the same grade obtained all the way up to the apex the summit presented the dazzling spectacle of an ice peak at least eight miles above the level of the seas. Think of tobogganing down a hill I,000 or I,500 miles long, and coasting all the way down the Mississippi Valley into Yucatan! I suppose that upon some such tales of real old-fashioned winter sports the gray-haired cavemen of prehistoric times regaled the cavedom "kiddies" 
before they were clubbed to bed for the night.

On my way back from the Loop this evening to the cliff in which we dwell in winter-time I left the car at Lincoln's monument for a walk through the park. The cold wave prognosticated by the Weather Bureau this time had not been side-tracked on its eastward way, as often happens in the vicinity of the Lake. There is real oxygen in the atmosphere. Fifteen minutes here amidst the creaking branches of the trees I am sure will change the color of one's blood. If you want an ocular demonstration of your own circulatory system you have only to look at those elms to observe your own trunk lines and capillaries. The scheme is the same wherever it is studied. Kinship is everywhere observable. There are five big cottonwoods standing in a clump. Their roots, as well as their highest branches, are closely intermingled; but they 


\section{In Winter Quarters}

seem to be dwelling together in unity, each adapting itself to the other, blending splendidly into one harmonious entity. A family group bound together below, and interlacing their lives up to the very topmost branches, I suppose they have their arguments and little jars both in the ground and in the air, but clearly in their union is their strength. Alexander Hamilton could not have made a better job of it.

Darkness settles early these December days, and there will be ice tomorrow where those shallow pools have been today. The creatures of the open will know tonight what Keats was talking about on St. Agnes' eve:

"Ah! Bitter chill it was;

The owl for all his feathers was a-cold,

The hare leaped trembling through the frozen grass,

And silent was the flock in fleecy fold."

This is the opening of the trapping season, and unless the statutes new 
and old regulating the taking of our fur-bearing friends are strictly enforced the shortage of useful pelts, now so apparent, will soon become much more acute. There is no longer virgin trapping territory. Not even in Alaska. Even in that remote region the beaver and the marten have now to be protected by a closed season to prevent extermination. Raccoon, mink, muskrat, otter, and even the peerless predatory skunk, now find refuge behind strict laws in various states. The killing of all these at times when their pelts are not prime is little less than a crime in these days of high cost of keeping warm in the winter.

In a cloudless, moonless sky even the glittering stars look cold, and after a day spent among books and mail and manuscripts dealing with pastoral pursuits, I note that Taurus and Aries -or in plain English the constellations known as the bull and the ram-are 


\section{In Winter Quarters}

shining brightly in the zenith. Pegasus, the winged horse, is flying in the west, and the grandest piece of jewelry we mortals shall ever see hangs resplendent in the east. If you don't know what it is, it is time you get busy and find out. And, lest we forget, there is Perseus almost directly overhead. But of him we are to speak again.

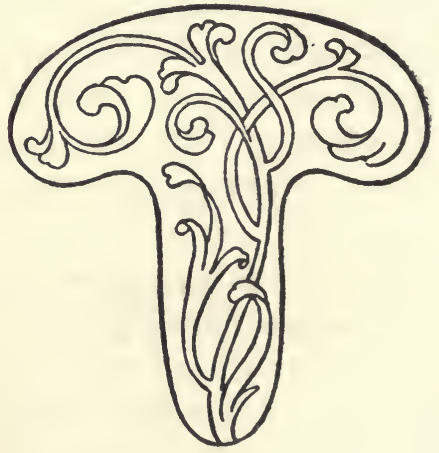




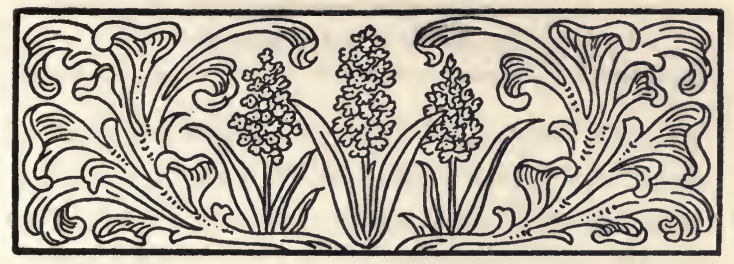

\section{II}

- Rattling the Chains

T $N$ my next incarnation, if I have I anything to say about it, I propose to be a free-born Mallard, for the more one studies the furred and feathered people of the open spaces the less he is apt to concede the alleged vast superiority of men over their fellow-inheritors of the earth. I do not desire to be written down a heretic. I have a decent respect I hope for accepted traditions about our having been given "in the beginning" dominion over all; but that statement, it must be borne in mind, was not made until men had already been on the earth for some four hundred thousand years. They had therefore ample time to establish might 


\section{In Winter Quarters}

as right long before the days of Moses and the prophets. Sometimes I think that it will be early enough to claim unlimited sovereignty over the rest of creation when we have first demonstrated capacity to run our own affairs in such way as to assure to each that measure of happiness which is the birthright of every man as well as of every chipmunk and purple martin. And my observations to date lead me to venture the statement that there is more real joy of life in leafy bowers, beneath sunlit waves, in mountain glades; in brief, wherever life other than human runs its normal course, than is found inside the doors of millions of mere men. From which it may be inferred that I believe that there are many lessons to be clipped with profit from our own old Mother $\mathrm{Na-}$ ture's book.

There certainly are times and occasions when one feels like asserting that the more highly civilized we become, 


\section{Rattling the Chains}

the more artificial our mode of living; the more man-made laws we substitute for Nature's, the more grief apparently overtakes us. The whole scheme being in many respects a departure from the fundamental laws of our being, naturally an unfailing harvest of disappointment is gathered throughout the earth. If under the established standards and conventions it requires four million different statutes, ordinances, courts, jails, asylums, policemen, poor farms, tax-gatherers, navy yards and training camps to enforce our man-made mandates, have we not reached the point where the sooner we are wiped off the planet the better? To the end that such honest, simpleminded people as the squirrels, pigeons and grass-roots may succeed to the Wilhelmstrasse, the Avenue du Bois, Trafalgar Square, Broadway, the Stock Yards and the Senate.

You may infer from this that I am somewhat of a rebel. Well, perhaps I 


\section{In Winter Quarters}

am potentially; made one maybe by long observation and a somewhat extended acquaintance with men and other mammals, saying nothing of those old gray willows across the way and the tulip bulbs hibernating in the turf beneath. From my library window I can see the bare branches of the trees nodding their approval this December day. They know one thing at least: that "the wind bloweth where it listeth," and if those wretched homesick Polar bears imprisoned over there behind the rocks and steel of the Lincoln Park "zoo," swaying from side to side from morn till night in endless misery, were to be asked their opinion of the ruling race, you know as well as I that their comments would never pass the censor.

I understand fully that such observations may read me out of the party. If so, I shall be sorry. Really I am not yet quite a cynic. I like some folks and certain of their ways. However, [20 ] 


\section{Rattling the Chains}

the truth is out of my system, and I shall go on of course, just as you will probably, trying as best poor human nature can to conform to arbitrary usages; and a lot of the rest of you, thinking as I do but afraid to say it, will also inwardly rebel, and then continue on your pre-planned course to the same transformation into dust that awaits that outlawed but vastly freer sparrow chattering there in blissful innocence upon the window sill.

What is the occasion of this outburst? Well, for one thing I suppose I had no business eating that kippered herring set before me at the breakfast table this morning. It never did agree with me. Besides, why pay seventeen prices for something hauled halfway across the continent over tracks costing $\$ 75,000$ per mile, when it only upsets digestion after you get it; and all this, too, in the face of the fact that my neighbor out there in the country puts up as fine a grade of breakfast 


\section{In Winter Quarters}

bacon, grown right here at home, as any epicure could covet. And anyone with half-sense knows that thin slices of that, broiled until just approaching the crispy stage, may be eaten with impunity even by babes! More than all this, however, there remains the really distressing fact that I had to close up Dumbiedykes, and move November first into a steam-heated city flat for the winter, and to this I was certainly a conscientious objector. I quit the open country under violent inward protest. That much I certainly admit. There was not sun enough inside those walls, no open fire, and you see if I had only been a Mallard I would not have been compelled to accept surroundings of this sort. This wide wild world would have then been mine; the sky, the sea, the air, the land, my heritage! "Thou shalt not" would not then for me be posted every fifteen feet to force the folding of unfettered wings. But, not being a Mallard yet, my life is not 


\section{Rattling the Chains}

altogether of my own ordering. In fact, far from it.

Our "duty" is defined for us by circumstances beyond our own control. Generations gone before have laid down the law. Presumably whatever is is right. At any rate, it does little good to raise the question. That clever Spaniard Ibañez has expressed this thought in his title "The Dead Command." We may not go our way even along peaceful lines free from the lash that others ply incessantly. Our brethren claim that right, and exercise it mercilessly notwithstanding the scriptural injunction, "Judge not lest ye be judged." People with heads not shaped like mine, and with hearts, stomachs, legs, hopes, aspirations and ideals differing wholly in character and strength from mine, dictate what I am expected to do or not do; basing their declaration of course upon the working of their own brains and livers, not mine. If I fail to observe their conclusions as 


\section{In Winter Quarters}

to what I may do, or not do, or should do, I shall be called to strict account. So what remains? Why just "conform" of course, insofar as your own limitations will permit, and, if you can, forget the Mallards and the Big Horn standing proudly on his mountain crag. Civilization is vastly more interested in those timid old Merino ewes being herded over there in that Government Forest Reserve. I wish I might talk as freely and frankly as Montaigne or Rousseau about some things; but one may not even find pleasure in watching with Thoreau a marsh-hawk's flight without some selfappointed Lowell landing heavily upon his back.

There are some few concessions at least to be truly thankful for. I do not yet have to buy the right to view the landscape, or take a walk, so long. as I keep off the property men say belongs to you. If my licensed dog is with me it will be advisable, however, 
here in town to hold him well in leash.

He can't chase himself through the flower-beds and shrubbery as he would dearly love to do. That is of course forbidden. Then, too, here where I live during the months when Sol is slowly working his way back into the North, I may still stroll through the, great park opposite where aged cottonwoods are waving their denuded tops majestically in the wintry wind, without being arrested; that is, if I can take time at a reasonable hour away from the sanctum down in the grimy, noisy, iron-bound "loop." One may even stop and admire those graceful elms without being told to "move on;" and if your eye be quick enough you may detect once in a while a downy woodpecker using his quick and microscopic eyes, let us hope with good effect, upon the wrinkled trunks and sturdier branches overhead. Indeed, from where I sit there are two views, the one inside the windows and the other 


\section{In Winter Quarters}

out, which I may dwell upon, according to my mood, without a meter marking up the minutes $\mathrm{I}$ am thus engaged.

Outside there are tree-tops, treetops everywhere. They are not the oaks of Dumbiedykes, but their myriad interlacing arms, sharply outlined against a leaden sky, are weaving waving pictures that only a "movie" camera properly placed could catch. And now and then, when the lights and shadows are just right, dim vistas of the distant heaving bosom of the lake project themselves into the finest etching in Chicago. No extra charge for that-except in the form of the ample rent I have to pay for the blessed right to be as near to Nature as is humanly possible in town.

Inside the walls I can look into the minds of a lot of congenial people, mostly bound in calf. A "baby grand" piano and Victrola stand ready always to bring the solace or stimulus of [26] 


\section{Rattling the Chains}

symphony or "rag" to supplement the saving grace of literature. The Black Swan andirons are not here, and the rustling of their fiery wings these winter days and nights is sadly missed, but the ghost of a boy who saw things long ago that others did not always see has found for me a partial substitute.

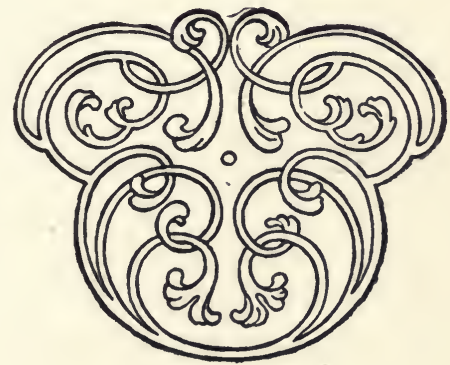





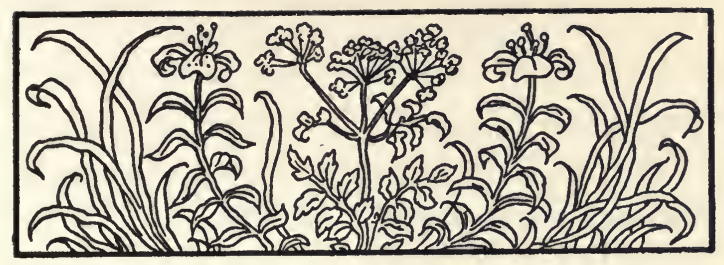

\section{III}

\section{Perseus or Pugilist?}

AN now I wonder would you care $A$ at all to know what fills for me at times the void occasioned by the absence of the open fire? An inexpensive picture. That is all. And only a photograph at that. I think it cost me about $\$ 2.50$ originally. I bought it, along with its two companion-pieces, in a little shop in the Via Sistina, many years ago, and will tell you frankly that the group attracts not half as much attention hanging over my study door as do other prints upon the walls. There is a little etching, for instance, of Chateau Thierry, showing the old bridge over the Marne, that is full of meaning now to all Americans. There 


\section{In Winter Quarters}

is another of the ancient "Street of the Clock" in Rouen, that appeals unfailingly to my imagination. Then there is a really nice example of Hedley Fitten's handiwork hanging just behind me as I write. It talks by the hour of Guelph and Ghibbeline, Cellini and Boccaccio; of all the wealth of song and story that the fair city of the Arno poured out into the world. The Loggia dei Lanzi in old Firenze! Then, too, a softly tinted rare old view of Windsor Castle sometimes calls for comment. But the masterpiece, the presiding genius of the little room of which I speak, my Perseus, is seldom noticed; save by some dreamer of dreams-some visionary non-conformist probably like myself.

I know little enough about art in any technical sense. But I know its power. I can feel its presence. We know that it forms the connecting link between ourselves and the universe of which we are all a part, and that the 
subtle something for which it stands effectively promotes the aspirations of mankind for something more than food and drink. We know that unnumbered thousands see or care for little apparently beyond mere creature comforts. We know that the fight for food, more acres, bonds or power over our fellowmen, obsesses most of us, just as corresponding ambitions and desires sway the actions of Poland-China pigs. The merely physical still rides its roughshod way.

I love the colors of a rainbow hanging in a dripping atmosphere and the dainty petals of the humblest wild flower in the woods, but could write no thesis on prismatic tints, on stamens or corollas. We marvel at old Sirius and Arcturus as they lead the winter or the summer stars across the sky, but some astronomer will have to tell us when bright Rigel rises or Capella sets. Anyone may catch the majesty of the Parthenon or Notre 


\section{In Winter Quarters}

Dame, but few will venture to talk pediments or flying buttresses to architects. I hear the entire pathetic story of "Thais" in that soul-sweeping "Meditation," but some one else will have to write of symphonies, chromatic scales and orchestration. Anyone may stand uncovered in the presence of the immortal canvasses and marbles of the world of art, but not every one can tell the story of either Leonardo or Praxiteles.

You therefore who understand the sculptor's art, that power supreme of calling forth the spirits that dwell all unknown to common folk within the rough Carrara blocks, spare me your all-unnecessary anathemas when I confess that to my own untutored mind the greatest statue in the world is just Canova's Perseus; that my large photo of it is my one chief household god, and I do not care to have my idol broken. It matters little to the world that this is so. But it means a lot to 


\section{Perseus or Pugilist?}

me, and if it helps me, it may help others too perhaps in some inscrutable or some small inconsequential way. I am not unfamiliar with the more ancient and more effeminate Apollo Belvedere. I have seen him also in that niche of his within the splendid galleries of the Vatican; and it is in that self-same room, beneath that same historic roof, you may find the lithe and militant Perseus and his perfect foils, the pair of brutish, big-necked pugilists standing by his side. This group Canova gave the human race to show a world that sadly needs the thought, the grace, and power of spiritual as compared with purely physical attributes, the infinite superiority of mind over matter, the radiant glories of the inspired ideal and the ponderous earthiness of unanimated flesh.

You may read the Persean allegory in any Greek mythology. You will know without the telling that the tale is clearly in its essence but the story of 
the triumph of good over evil; the eternal supremacy of the powers of light over the demons of darkness. If you were to see my photograph you might or you might not catch the shining beauty of the figure, instinct with life, poised ready for any flight; his feet not glued to earth as are those of common clay. Plainly he relies not on a burly body for his superior power. His the resistless strength that flows perennially from contact with and understanding of the Universal Force! Mark the ethereal ease! The tenuous grace! The obvious incarnation of beneficent, unfettered power! Exalted and refined beyond description!

Men need not all be brutes, and those who are so inclined might profit by a study of this pagan Perseus. It seems difficult for preachers to lead you to Christ for an example. Maybe some inkling as to what the divine fire really means in man could be gathered from the contemplation of a statue, 


\section{Perseus or Pugilist?}

which I had rather own than possess a deed in fee simple to Chicago city. The one would lift me up sometimes. The other frequently depresses. And if the Italian Government could only be induced to let us have this marble group in full payment of its war loans from the United States, and if some Ogden Armour would then give a million dollars to be expended upon the building of a worthy Pantheon to house the figures, facing the Auditorium on the Boulevard, some real conception of the higher things of life might be brought home to this big-bodied, busy, sordid, money-grubbing town.

The average man seems to be about nine-tenths physical and maybe onetenth mental. He is so busy catering to the former that he has no time to bother with the latter. Not content with living upon the food that produces itself all around him, not content with clothing himself with materials near at hand, he sets out to scour the remotest 


\section{In Winter Quarters}

corners of the earth for new dishes to placate or damage his stomach, or new fabrics with which to deck his person. To this end he organizes business-big business. To this end he creates what he calls commerce. To this end banks, railways, steamships, telegraphs. To this end all the complicated machinery of modern industry. Hence a thousand grocers to one geologist; ten thousand plumbers to one poet; an army of meat-cutters escorted by a few musicians! Millions at Washington for artillery; not one cent for art! It is glorious, is it not, to see Willard's bloody face after Dempsey has "landed," but I never saw any mob fighting for places to see "The Dying Gaul" in bronze.

Perseus exerts upon me always an uplifting influence. I wish you all might see him; for like the flaming logs of an open fire he has the power to carry me in fancy over Hyperborean seas, across Libyan sands, and up the towering heights of Helicon itself. 
Just why I cannot fully analyze. All I know is that he does. But if by chance you should be curious enough about it to order a copy from your dealer, do not fail to ask for all three of the figures. The spirit-beauty of the demi-god is clearly emphasized by reason of its utter absence in the pugilists. So in this group I find the underlying basis of my protest, and realize its hopelessness. Mortal men are merely clay, and will never be anything else. They will therefore continue beating one another up in spite of laws and Leagues-or else by virtue of them-until the judgment day, and incidentally kill bluebirds to their hearts' content

Canova's super-man is but a master's marble dream. Still peace and rest and hope are sometimes found in dreams. The trouble is we commonly awake only to be confronted somewhere by the Gorgon head that turns our noblest aspirations into stone. 



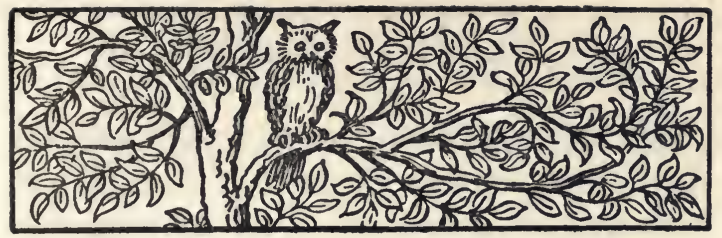

\section{IV}

Seeing Things

ROWSING around in the library $B$ the other day, I came across some old school books that had somehow survived the wreckage of several different homes. Such household effects as carpets, rugs, beds, chairs, bureaus, "high-boys," dishes, draperies, dogs, cats, canaries and gold fish do not always live through family hegiras and mutations, but books-old school books in particular-seem to have nine lives. A really human interest attaches to them because certain individual characteristics are in most cases indelibly stamped upon them; and these, viewed in after years, in the light of subsequent developments, are often 


\section{In Winter Quarters}

more or less, illuminating. The owner in this case is still living, and I am well acquainted with him. He doesn't know half as much now as he did when he first graduated, but is still studying, and is firmly of the opinion that by the time he is forced to stop he will have reached the point where a little real knowledge might begin to be accumulated. But when the old school bell called him for the last time with these books he honestly thought his education was finished. Interesting to fall upon an old spelling book that once occupied a real place in the life of someone you have known, isn't it?

The owner of these old books had one obvious obsession: Each and every big round $\mathrm{O}$ appearing on the title pages had been transformed into a face with eyes, nose and mouth duly inserted inside the circle, with a pair of ears on the outside. The latter were sometimes small and placed humanfashion at the sides of the $\mathrm{O}$, but more 
frequently on top, in which case they were apt to be of generous height and pointed. The mouth was always of cavernous dimensions, and curved sharply upward at each end, giving the creatures thus called forth from their typographical ova a bland and smiling countenance. If there happened to be space enough on either side of these big O's an elongated body was fitted up against the face, to which four legs were attached; the front ones projected well forward, and the hind ones extended far toward the rear, giving a certain effect of exceeding all known speed limits. A gaily up-curved tail of generous proportions, invariably thrown well forward over the quadruped's back, completed this somewhat startling delineation of a wildcat or some other moon-faced nondescript tearing through space with its grinning face, broadside on as it galloped along on its apparently happy way, across the title page of some [4I] 


\section{In Winter Quarters}

well-worn grammar or arithmetic.

The fact is the boy was known to have a sort of mania for discovering faces in all sorts of unexpected places: sometimes in the fire; sometimes in clouds; sometimes in the rocks; sometimes in the trees; sometimes in flowers; sometimes here; sometimes there, but always and forever he was finding pictures that were apparently overlooked by most other people. And it was rarely he took the trouble to ask anyone else to try to see what he was seeing. Sometimes after a lot of explanation someone would grudgingly agree, but more frequently on such occasions he would be told he was crazy, and that there was nothing there at all. This he resented because he knew better; and when something of particular interest appeared he felt very sorry sometimes because companions did not share with him the humor of some visionary gargoyle's grinning countenance, the elusive 
witchery of a vapory profile in the sky, the majesty of some stately statue on the distant hills, or maybe a queer expression painted on a pansy's petals by the sunshine and the rain.

$\mathrm{He}$ made friends, too, in the woods. Faces were found where knot-holes scarred the trunks of trees. Outlines of birds and beasts were seen along the banks where bluebells and infinitely dainty lady-slippers blossomed in the early spring. And how happy he used to be when near some moist, warm spot the first "Dutchman's breeches" were hung out on the line by some fond waking mother! $\mathrm{He}$ caught its close resemblance to the bleeding heart of everybody's cultivated garden, and while he laughed at the singular appropriateness of its common name he always felt that whoever first called it "fat-man's trousers" was guilty of a most atrocious offense against one of the first and fairest of all the northern wildwood's gifts. 


\section{In Winter Quarters}

As a lad he was of course familiar with the old proposition that if one were to journey to the spot where the ends of rainbows touch the earth he would be rewarded with a pot of gold. For a long time he took this very seriously, and often tried to figure out just how many miles away this would lead him if he actually set out to get the coveted treasure, of the existence of which he had not the slightest doubt. But I do not remember that he ever really started on any of these projected expeditions. He has since discovered, nevertheless, that some rainbows bring to those who understand them more than gold.

His facility for finding hidden qualities and real companionships in almost everything from crickets to constellations has never been altogether lost, and its exercise has often proved a better sedative than bromides. It pays sometimes to turn one's back on men and study the antics of an ant, 
even though you draw with Mark Twain the conclusion that the busy insect's fabled wisdom is a myth. You may watch cats or catbirds by the hour and see something new about their mental processes nearly every minute. And if you know when and where to look for the first trillium or the rising of Orion you will have found unselfish friends outside the daily grind that it will pay to cultivate. And there is worse company in this world than that of yellow corn-blades rustling in the late September breeze.

Among these other relics of this boy's youth I found an old greenbacked Harkness Latin reader, made up mainly of selections in simple classic language from ancient fables. Its pages are nearly all more or less disfigured with all manner of lead pencil notations. The blank leaves that bookbinders seem to regard as necessary in the front and back of every volume were apparently greater favorites with 


\section{In Winter Quarters}

the owner than those that carried his lessons; being filled with names of playmates or quotations or comment of some sort on whatever happened to be, at the moment, in his thoughts. The star line, however, scrawled in big letters with a lead pencil in the front of the Latin reader is: "Silens Aqua Currit Alta."

While the sentiment underlying this was of course far from original, the Latin was his own, and he never took the trouble to ask any real scholar how far he had missed his way in trying to Romanize a hackneyed phrase. The old superintendent of the school was in the habit of going around from one room to another hearing lessons at different hours in various studies. He was the kindliest old soul that ever lived; wore long whiskers becoming silvered toward the last; and was professor of everything. I am quite sure that he did not know a lot more about Latin than the children he piloted [46] 
through the first declensions, and when one day, in response to a previously preferred request, each pupil had to rise in turn and express in the ancient tongue some "motto" or sentiment of his or her own selection, this boy worked off the line he had written carefully down in his book, for fear he would forget it at the critical moment. $\mathrm{He}$ had not thought of the incident for many years until he saw the old green-backed book this afternoon, but is still prepared to stand by the proposition that "still waters run high" as well as deep.

That book brought his first acquaintance with Æsop, and he has a very vivid recollection of the impression made by the story of the boy who smilingly denied having stolen a fox which he had concealed inside his tunic, even while Reynard was gnawing at his very vitals. Of course he missed the point of the fable at the time. He loved the Esopian gossip 


\section{In Winter Quarters}

about what all the different animals said and did, but when the story was ended, and the inevitable lesson was to be impressed, his interest rapidly waned. He was not specially concerned in those days with the morals drawn by the wise old Greek from these simple tales, but he now understands the story of the Spartan youth, for he has since seen people trying hard to smile when something the world could not see was evidently gnawing out their hearts. He has known some who have failed and fallen in their tracks because they could not free themselves from that which was destroying them; and so has passed the point of pronouncing judgments that may be harsh as well as hastily and incorrectly formed.

The storm tonight is making fairyland of all the landscape, and incidentally working heavy damage to the overloaded branches of the trees and shrubbery. Electric lamps are gleam- 


\section{Seeing Things}

ing brightly down the winding roadways. Most of my evening has been spent watching the flying flakes settling silently in the leafless wood. On such a night old Santa used to ride, and children tucked away in soft, warm feather beds dreamed of the coming of their one great day of all the year.

I have forgotten all the gifts one boy received one Christmas morning, but I know there was a sled with white swan heads in front, gay with paint, and carrying on its back the legend "Snow Bird." And it lived up to its name through many a joyous hour upon the hills. And skates! Yes, the kind you used to see-wood, shod with steel, curved up in front. Out south of town there was a marsh where muskrats had their homes, where boys could find red cheeks and great adventure! The river, too, was near, and up and down its winding course, where the willows, oaks and sycamores were waiting for the spring, a noisy lot 


\section{In Winter Quarters}

equipped with good stout clubs contested fiercely for a block of wood in a rattling good old-fashioned game that need not here be named. And on the bank a fire of leaves and twigs and sticks and stumps and old dry logs sent up its incense to the happy skies of youth.

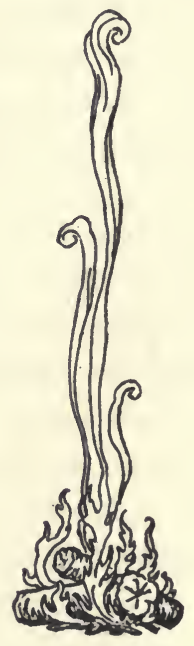

[50] 


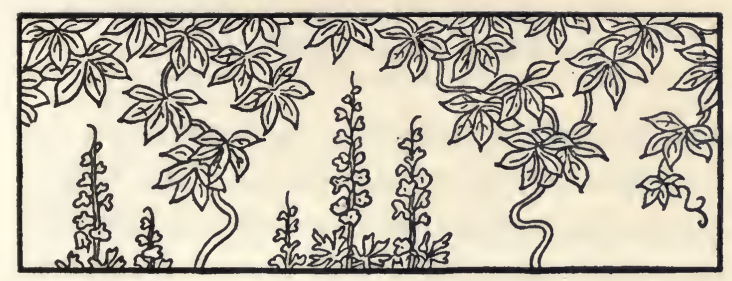

$\mathrm{V}$.

A.Governor's Gift

T $T$ was not all play for the boys of 1 that community. Like the colts among which they were reared, they were taken in hand early, and made to feel the weight of light harnesswhich with most of us is quite soon enough exchanged for the heavy gear with which real loads have always to be hauled, and this is the story of how one boy's "breaking in" was undertaken. The beginning of it he remembers as well as if the words had but yesterday been spoken:

"Take this, my son, and hoe your way through the world with it."

The speaker was a distinguishedlooking, elderly man; the place a hard- 


\section{In Winter Quarters}

ware store in a little country town in a mid-west state; the time many years ago; the article alluded to a child's toy hoe, modeled on the regulation garden pattern. As to the youngster's identity, that is a matter that would interest nobody in particular. Suffice it to say that he has been hoeing hard ever since; in fact, is still working his way down a long, long row, the farther end of which is now coming into view. And as he hoes sometimes he talks; not always to any special purpose, and not often with any profit to himself or anybody else, but at times he finds a certain degree of satisfaction in trying to get in touch with others who may have been compelled, as he was from the beginning, to walk and hoe, instead of ride and go where fancy or inclination might suggest; only there are probably not many who will care to follow him.

Alvin Saunders, whose words quoted above were addressed to a small boy 


\section{$A$ Governor's Gift}

on a certain memorable occasion, was the Civil War Governor of the state of Nebraska, one of a strong group of Unionist executives that included such towering figures as Samuel Kirkwood of Iowa, Richard Yates of Illinois, and Oliver P. Morton of Indiana-men who held their respective states firmly in line for the policies for which Abraham Lincoln stood, in the face of the under-currents of opposition set in motion by sympathizers with the Southern Confederacy residing in these and adjacent states, well organized under the name of Knights of the Golden Circle. The Nebraska Governor had retired to private life after the close of the War of Secession; and it was not many years after Grant had handed back Lee's sword at Appomattox that there was placed in boyish hands the symbol of honorable service represented by the tiny garden tool already mentioned, and at a later date Governor Saunders was sent by 


\section{In Winter Quarters}

the state he had already served so well to the United States Senate. The occasion of his presenting this boy with the little hoe, and the situation that drew forth the injunction that was passed with it, arose from the fact that the boy had been named for the Governor, and he took that method of acknowledging this action on the part of the boy's father, who was a distant relative. One branch of the family had injected an extra vowel into the spelling of the tribal designation, which I should say was corrupting a really sound old Anglo-Saxon name.

The prospective visit of the Governor to this boy's father's modest home had been a topic of conversation around the family fireside for some time. It was no ordinary honor that was to be bestowed. The great man had never seen his little namesake, and had, it seems, signified his intention of coming for that purpose, and incidentally of course to renew a personal acquaint- 
ance and friendship with the parents. And so it chanced that the boy's first knowledge of what sort of thing a "Governor" really was came to him when he was probably six years old. He had heard a lot about the Governor's coming, but when the great day arrived he relished not at all the idea of meeting it face to face. As a matter of fact, the boy had never been more thoroughly alarmed than on that fateful afternoon. He avoided the house as the hour drew near, but presently he knew that the Governor was in the parlor. That sanctuary was not opened up in those days except upon state occasions, of which this was of course a most important one. I suppose the black haircloth on the chairs might have been damaged if light were admitted. The green "shutters" were drawn as usual, but, determined to get some sort of preliminary notion of whatever was now inside before having to undergo the ordeal of meeting it, 


\section{In Winter Quarters}

the boy cautiously peered in through the window-slats, and made one of his first great discoveries. A Governor was "nothing but a man." He was really disappointed, as well as more or less disgusted, and promptly so informed his mother.

The fact is he had not been given any information upon the subject. It had been taken for granted that any child would know without telling what a Governor was, but unfortunately this one didn't. He had not the remotest idea as to whether it had two wheels or six. Or whether it walked or crawled. Anyhow, he found out, at least about this particular one, and this is what happened: The Governor and the father were great friends. The guest stayed all night, and the last thing the boy remembered when sent to bed was hearing them threshing out the Civil War. Next morning he was invited to go to town with them, and was taken to the store where the little 


\section{$A$ Governor's Gift}

hoe was duly bought and placed in his possession. And it was not many years before a real sure-enough implement of the same type displaced the toy the Governor had given, and a work and an education as yet unfinished was begun.

The boy does not now remember just what he did with that first hoe. $\mathrm{He}$ does recollect, however, that after the great occasion of its formal presentation his father had tried to explain its real significance.

"My boy," he said, "you' must understand that the Governor did not expect that you were always to keep this particular hoe and try all your life to earn enough with it, in working for someone whose garden needed hoeing, to make a living for yourself."

That was a little beyond the boy's depth, somewhat over his childish head; but the father elaborated the proposition in such manner that the underlying idea was vaguely caught. 


\section{In Winter Quarters}

"It means," he added, "that you are always to try to help yourself along. Do something with your own hands, and not wait for someone else to come along and do the work that is before you waiting to be done."

That was plain enough truly, and then followed something like this:

"It does not mean that you are actually to hoe with this little hoe always; nor does it mean that even when you are a big boy, and afterward a man, you are never to use anything but just a common hoe. It means that you must work hard and faithfully at some kind of honest labor, and so become able to take care of yourself, and not be dependent on anyone else."

That was more or less illuminating and of course gratifying, for the boy was not sure, fond as he was even then of all garden life, that he really wanted to hoe weeds all his days just because a Governor had placed the necessary 


\section{$A$ Governor's Gift}

implement in his hands with an impressive adjuration as to its indefinite, indeterminate use.

Thus opened one of the first important epochs in a child's early years; thus did the gospel of work and selfdependence receive its first parental preachment; thus was one boy's hand placed upon the ladder of labor, up which all, save those who are so unfortunate as to be born with a gold spoon in their hands, have to climb by their own efforts, or ultimately fall. And it was not long before he had to hoe for the wherewithal to maintain himself properly on certain occasions in this little town of Boyville; and he has not yet seen the time when the hoeing could be altogether stopped, if pace with modern civilization, and present-day standards of living, is to be maintained; and he is beginning in his later years to question somewhat the soundness of a social state that compels this endless grubbing, when 


\section{In Winter Quarters}

under simpler standards, under less constant pressure, time might be left for something better than trying to establish incomes-the major part of which is claimed by butchers and bakers and limousine-makers, and the residue requisitioned by the Federal Treasury.

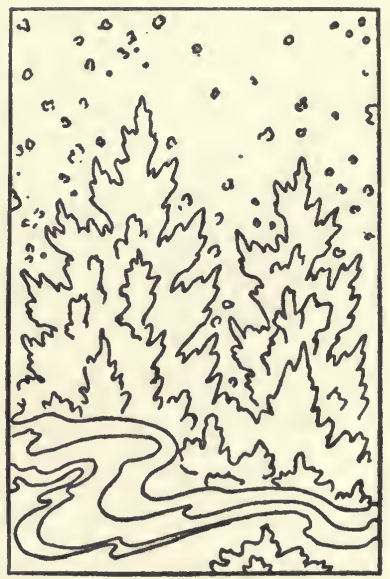

[60] 


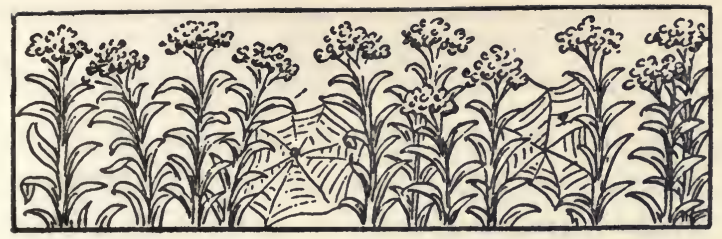

\section{VI \\ Going Back}

SOMEHOW I have felt a peculiar $\mathcal{N}$ exaltation of spirit this afternoon as I sit here in the window watching the crowds of youngsters skating yonder in the park. Fond as we are now of a few weeks each winter at Palm Beach, or maybe Coronado, I know perfectly well that if I were compelled to select anew a permanent abode, and had to choose between the Yukon and the Amazon, and you cared to know which way I had passed, you could send your searching party somewhere into the North; not perhaps to the great white Arctic wilderness, but at least within hailing distance of "the roaring forties," where the rocks [6I ] 


\section{In Winter Quarters}

and the waves, the hemlocks and the pines, voice the never-ending struggle that is life, demanding always the best one has to give.

It may be that there is more real happiness along the Congo or the Niger than can be found on Riverside Drive, but one thing is certain-red beef, white bread and blizzards breed sterner-fibred brains than are commonly possessed by those who grow bananas instead of bullocks, who prefer the milk of a cocoanut to good certified Guernsey, and who wear palm leaves instead of sealskin.

There is everything, however, in the permanent gripping power of early associations. Winter really ushered in most of the good times enjoyed in the community where these early experiences in life began. True, there was live stock still to be tended just as in the summer dawn and dusk; and wood had to be chopped. These "chores," however, in willing hands were quickly 


\section{Going Back}

managed; and looking back to these beginnings I can easily see that what appealed more than anything else in life in the days of which I write was that which came with the iron clamor of the big school bell's tongue sounding across the village roofs and open fields; a call that will ever be associated in one boy's mind with the coming of the frost. He confesses to a fondness still for drifting snows. A withering August sun recalls too many old-time dog-day drudgeries. Did you ever hoe corn or potatoes all day in July? Did you ever milk cows and carry "swill" to a hundred hungry, squealing pigs after a hot day's work was supposed to be done? And no swimming hole within a mile, and no bath tubs in the house? Ever stow hay away with a pitchfork in a mow under a blazing roof? No? Well, some of us have, and the pleasantest memories of our youth do not all date from those inevitable mid-summer tasks. How- 


\section{In Winter Quarters}

ever, the picture had another side. And, more than that, they manage these things much better for the boys throughout the growing season on most farms nowadays.

I am sure that this boy loved his parents at least as much as the average active, normal, ragged, barefooted specimen can. Nevertheless he had a standing quarrel with his father as to the funds to be burned on "the Glorious Fourth" - that being one of the few red letter days that relieved the long and strenuous weeks that began with the heated term. This was due to the fact that, as yet, he did not altogether comprehend the full significance attaching to the giving and receiving of that hoe. Usually he was compelled to earn his own meagre accumulation for that great occasion, and opportunities for small boys to get actual cash for any service they could render were in that particular locality not at all numerous. The one certain 


\section{Going Back}

annual source of revenue in the neighborhood was an adjacent farm devoted to small fruit and berry culture. When the strawberry beds had blossomed, and at last the sweet red product had ripened on the vines, old "Uncle Billy" Waite, the owner of all that lusciousness, would send for the children to help harvest the crop.

It would be back-breaking work for that boy now in these same sunny fields, but it was not altogether a hardship in that blessed land of yesterday. First of all the outfit ate about as many berries as they picked, but in addition to that the generous-hearted employer paid I 5 cents an hour for the work in real money! I think the boy earned as high as $\$ 3.75$ one big year. True, he could have burned up in five minutes Fourth of July morning what it had taken him more than ten hours to earn, but he didn't. Not much! Those little red Chinese "crackers" were altogether too precious for the [65] 


\section{In Winter Quarters}

indulgence of any such foolishness as that! He fairly worshipped each and every individual member of each pack, and attached to the lighting of each one all the importance and seriousness of a really important ceremony. And how disappointed when one of these would only "fizz," not crack! Anyhow, by hook or by crook he managed to do practically without his father's lack of financial support in this fire-cracker and torpedo business, thereby writing for the first time his own Declaration of Independence. Probably the father understood well at the time the lesson being inculcated, even if the boy did not. And his mother likewise took a hand in seeing that the hoe did not rust for lack of use. The lesson as to the necessity for labor as an essential factor in one's daily life was not, by this boy at least, to be forgotten.

All children who are properly brought up have occasion now and then to resent maternal control. I 


\section{Going Back}

know this boy was often compelled to do things around the house that he regarded at the time as altogether unreasonable; the most memorable of all these arbitrary exercises of authority of which he still has a distinct recollection being notice given one Circus-day morning that he would have to "churn"! Now everybody knows that in the small interior towns of the days of which I write, far removed as they were from railways, the coming of a one-horse show was looked forward to for weeks by every "kid" in the community. We had agreed to meet early at Charley Silverwood's. The name is remembered because never heard of anywhere else before or since. If any of you ever saw a boy working off energy on a dash churn that might have been expended carrying water to the elephant or something, you will know that it was a long and tedious operation to reduce good cream to butter and buttermilk with that anti- 


\section{In Winter Quarters}

quated dairy utensil. Science had not yet given the separator to a weary, waiting dairy world. Churning was woman's work anyhow. Just the same it had to be done; but no house service he ever rendered was gone about with fiercer rebellion in his heart. Of course he did not tell "the gang" what it was that kept him away entirely from that fondly-anticipated rendezvous, for that would have been the signal for too many humiliating jeers from "Skinnay" and the rest, and so one of midsummer's few great days of the long ago for him was all but ruined.

All in all therefore the end of summer brought few regrets, and it was a happy bunch that responded to the school bell's clang in late September. It was hard sometimes at first, especially when dreamy Indian Summer days had come, to be penned up inside when mysterious woods in scarlet, gold and brown bedecked were calling ceaselessly, for all boys knew that after [68 ] 


\section{Going Back}

every frost the nuts were falling fast; that hickories, walnuts and butternuts were waiting to be sacked for wondrous winter nights to come. The grapes hung purple on the vines, and orchards richly-laden spoke in accents plain of big red apples, cider, popcorn balls and fun galore around the roaring fire when work was done.

Strange, isn't it, how the consciousness of something vastly important but previously unknown can be suddenly and indelibly impressed? Certain boyish sports are ever to be associated in memory with unnumbered happy hours, but it was on the wings of a typical western blizzard that there was brought to this boy the decidedly disturbing fact that girls also had a place in the general scheme; and that great discovery, with all its potential joys and sorrows, made one stormy winter day, clears up any remaining doubt as to why cold weather at one time had such strong appeal. 


\section{In Winter Quarters}

There are no thrills whatever in the little tale I am about to tell. It is just a plain narration of an experience essentially human, and therefore necessarily common. And yet any incident that marks the first faint rustling of an angel's wing, old as the story is, must yet be ever new and sometimes worth the telling, even though it relates, as in this case, only to a twelve-year-old boy whose central idea of happiness up to that date had been, as a matter of fact, based mainly upon considerations affecting his own comfort and convenience. So this is how he took another step.

In the midst of a good old-fashioned snowy winter, one of those blizzards that were in the early days a real terror to travelers on the western prairies burst in all its fury while school was still in session in a little country town. Word was sent out to fathers and mothers to send for their little ones, and see that they got safely 


\section{Going Back}

home through the blinding storm. 'The older ones braved its biting blasts, and as they always had books and slates, as well as empty lunch boxes or pails, to carry home the trip upon this particular occasion was sure to be a strenuous one, for it had turned intensely cold by the time the classes were dismissed. The principal and teachers in the various rooms were much concerned, for the days were short, and after all had waited long and vainly for the fierce, keen-cutting storm to moderate its fury, the evening shadows threatened, and the order came to don wraps, scarfs, overshoes and mittens, and start for their respective goals.

There were two homes in the farther edge of town, distant more than a mile from school, towards which the steps of one boy and a neighbor's daughter had to be directed. They had never been known to make the trip together. From the boy's point of view that would have subjected 


\section{In Winter Quarters}

himself to the deserved ridicule of every one of his boon companions. More than that, he was not conscious as yet of any particular desire to walk by this girl's side. She was a year or two his senior, red-cheeked, vivacious, popular. Under ordinary circumstances he would have raced straightaway of course, with his accustomed playmates, but such was the sobering influence of the storm-which for some years afterwards was referred to as the worst within the memory of the oldest inhabitant-that for the first time in his life he felt a strange new fear that danger lurked in that blinding frigid gale and the pathless ways for this one girl. It did not occur to him that any other girl in the whole school stood in need of such little aid as he might render, and, notwithstanding the fact that he had an armful of his own impedimenta to manage, with an assurance hitherto entirely foreign to his nature, he insisted upon adding to [ 72 ] 


\section{Going Back}

his own burdens her geography, arithmetic and composition book, and I know not now what other schoolroom accessories which she thought from force of habit she had to have at home that night around the evening lamp. But they had not gone far before the real size of the boy's contract became apparent.

Side by side they fought their way tediously along, the girl at length considerately asking that her own books be given back; but the boy was game enough, I am glad here to record, under the spur of some new strength to turn deaf ears to that appeal. True, his fingers and his ears were aching, stinging terribly in the icy blasts, and he was so laden that he could neither bat his hands to keep them warm nor press a mitten tightly to the side of his freezing face, although he dearly wanted to do both. He had undertaken to carry those things home for her, and carry them to her home he would, 


\section{In Winter Quarters}

unless insurmountable snow-drifts stopped him before her parental threshold could be reached. To dwell upon that wintry journey, not of "two babes in the woods," but of two children through a record storm, is scarcely necessary. The main thing is that they at length arrived. The girl in her furs was all right, but that boy's mother, believe me, all who have followed this prosaic yarn thus far, had one busy hour trying to extract the frost from his various extremities. Toes and fingers came through the ordeal without serious injury, but to this day his ears feel instantly and acutely the teeth of low temperature.

It is not of any physical discomforts, temporary or permanent, resulting from this youthful experience, that the boy would here have me speak, but rather he would have recorded the simple fact that such pain as he endured that day and night and for succeeding days and nights was swallowed 


\section{Going Back}

up completely in the belief that he had rendered an actual service to one who in the twinkling of an eye had thus strangely become invested in his sight with attributes not possessed by anyone else. And for a long time after that not even his pet dog nor pony meant as much as she! He was glad that he had frozen his ears in such a worthy cause, and would have done the same thing again, maybe even more, if occasion had offered in an environment so nearly barren of dramatic possibilities.

Thus was another little step in a boy's education taken, and the sound of that last angry howl of the Lake Michigan gale tearing by my bookroom window tonight recalls the picture of two children fighting their way one winter afternoon from an old brick school-house, that may be standing yet, to their neighboring homes outside a town that was once the world and all to both of them. 


\section{In Winter Quarters}

Did you ever read Will Allen White's clever sketch entitled "The Homecoming of Col. Hucks"? I think more of it than of a lot of other stuff the versatile and talented Emporia editor has since erupted. Well, the colonel was a Kansas worthy, a leading citizen who had made good in the west, in worldly ways at least, and finally went back with his wife, as I remember it, to revisit his early Ohio boyhood haunts, only to meet with one blamed disappointment after another in seeking out various once familiar scenes. Nothing was half as big as it used to. be! Distances were infinitely less! The whole business had somehow shrunk and shriveled up until what shildhood's fancy had painted into something almost sublime had suddenly become fairly ridiculous; so that the Huckses went back to Kansas more or less disgusted, and of course better satisfied then ever with their western environment. 


\section{Going Back}

I know just how Hucks must have felt, for not so many years ago a boy revisited the old home in Iowa, and vouches for the strange and absolutely unaccountable, in fact impossible, changes that have come over certain well-known areas and dimensions. For many years, when he was a very small specimen, there was no railway line through the county in which he had been born. His father was the owner of a small private bank that faced the great brick Court House in the public square, and one of the boy's earliest recollections had to do with a string of oxen, probably six or eight pair, straining and leaning heavily in their yokes hauling a great steel safe being transported over land from a shipping point some 30 miles distant. $\mathrm{He}$ will swear that this safe stood at least I5 feet high, and it was painted green and letters on it spelled "Herring," and it came from Cincinnati. Maybe that may mean something to some of 


\section{In Winter Quarters}

you old bankers or modern steelmakers, and maybe it will not. Anyhow, the boy knows now that this great pioneer safe-deposit thing was possibly six feet high, not more.

I could tell you also of a little incident connected with the construction of a railway through the sleepy old village of this same boy's youth. At one point the locating engineers were forced to run the line through a hill, and across a ravine. I use these words advisedly, because when the construction gangs did the work a small boy stood for hours watching the great "cut" and "fill" gradually being brought together at the requisite grade, and knew therefore from firsthand source what a stupendous undertaking it really was! Do you care to know how deep that cutting is now, and that self-same "fill"? I will be liberal and record the fact that they must be somewhere between 15 and 20 feet! That boy will never forget 


\section{Going Back}

the shock of making this wretched discovery. In fact, this enforced rectification of supposedly well-established physical lines so jarred his imagination that he knew at once that his child's house of cards was to be immediately and everlastingly demolished, and it was.

Do you know that the old marsh where the mallards and the muskrats used to feed had disappeared entirely? That corn and alfalfa are now growing where once he used to skate? And must he tell you that the river where the "shinny" was played and the great bon-fires built is now just a plain, every-day shallow creek? In the interest of the truth must he also confess that what the boys called the creek is little more than a dried-up open ditch, the timber all cut away from its once thickly-wooded banks! And in "the old swimmin" hole" in one of the bends where he knew he had caught hundreds of bull heads 


\section{In Winter Quarters}

and tiny sun fish there is not now water enough to float a good-sized chip!

Thus perish cherished illusions one by one, as our education progresses. I bury a new one every few years. I can name one thing, however, that is constant and changeth never. The note that dominates tonight the wild music of the wintry wind lashing the ice-bound branches of the trees is the same as when the world was born. It mourns for the beauty that fled with the early frosts, but the snowflakes that follow in its wake bring the neverfailing promise that all shall come again.

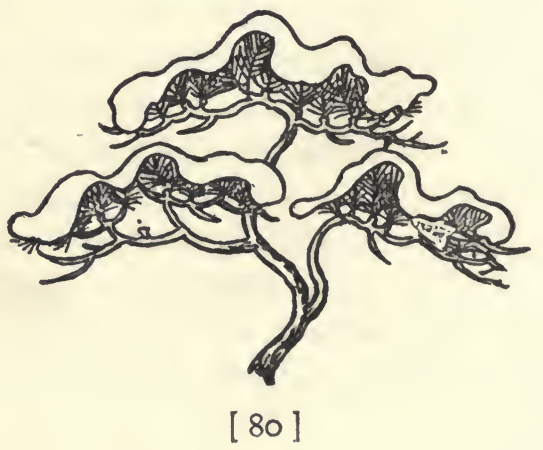




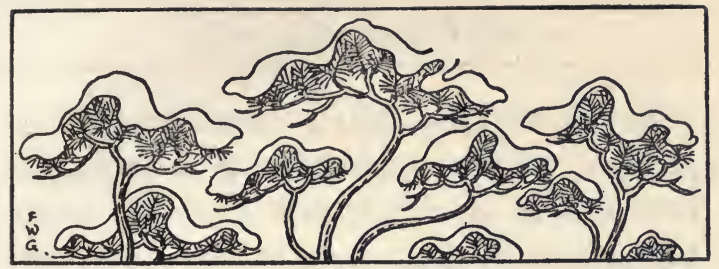

VII

When Snows Are Deep

MID-WINTER has its high W Olympian hours no less renowned than summer's halcyon days -if you only think so. Content or discontent, happiness or unhappiness, joy or sorrow, at all seasons, are at bottom merely a state of mind superinduced largely by a state of the body. A jolly snowstorm that sets redcheeked school children wild with joy, excites little enthusiasm in an asylum for the blind. The world is a delirious dream of pure delight to those in health and who, at the moment, are having all their fondest wishes gratified. How can anyone ever be weary of it? 


\section{In Winter Quarters}

Some day when a heavy snow is falling, put on your cap and coat and boots and mittens, cut all your wires behind you and head deep into the woods. Not those man-planted ones in Lincoln, or any other, park or in ornamented private grounds, but God's own woods, where the briars and brush and undergrowth still form the surface-mulch for big old oaks or pines or sycamores. You will gain more there in an hour than you can make anywhere else in a month. That is, unless all those attributes that belong to man as the Lord intended him to be, have been bred out of you, as the horns have been bred off certain types of animals. Unfortunately twentieth century standards are steadily transforming us from wholesome natural rational beings into something not found on Creation's list of original specifications.

Go out into the forest when the great, lazy, six-pointed crystals are softly sifting downward through the 


\section{When Snows Are Deep}

trees, when all paths and trails and roadways have been freshly buried, when Aeolian waves of harmony rise with muffled roar and die away and rise again as the swaying wood responds to the baton of the master of the storm. Do not hurry. And now and then "stop, look and listen." Some train de luxe, with its ill-ventilated steam-heated compartments and deluded passengers on their way to scenes supposed to surpass those in the midst of which you are standing, may be flying somewhere in the far distance, but you are safe. You are not only in no danger so far as any actual impact is concerned, but the atmosphere in which you are enveloped would analyze quite free from toxins. I know the Pullmans are thoroughly disinfected at the end of each trip. But the fact that this is necessary supplies the proof that people will leave home to run into that which finds no abiding place under this old bass- 


\section{In Winter Quarters}

wood standing so serene and steadfast in his spotless garb. Those drawingrooms are all right for those who have to go. So are the theatres the Shuberts syndicate. But I know people who would be quite as well off if they patronized a snowy woodlot more and courted the streptococcus artificialis less.

There is a strange, mysterious, soothing quality in the woodland snowstorm that you do not get in the more savage blizzard that blows almost horizontally across a wind-swept prairie. In the forest thicket you feel the presence of all sorts of co-related life. All is so still, save the tossing treetops. All so tranquil. All so intimate. You are so near the heart of so many things. The spirit of solitude spreads like a benediction throughout the world in which you stand. No dry leaf, or twig, or stump, or stone, or brush, or branch is forgotten by the flakes. They are so fair, so frail, so pure, impartial and in[84] 


\section{When Snows Are Deep}

sinuating. A loving tenderness seems to animate each cloud-star as it nears its resting place. With what inexpressible poetry of motion it wings its way amongst the outstretched waving arms through which it passes in its downward flight. It comes to shelter, save, insure, protect. Some day it will hear a sun-ray call, and disappear beneath the sod to fulfill another purpose in the endless cycle of its destiny.

Even the birds and burrowing furbearers seem to sense in the sky-born visitation a semi-sacred ceremony staged primarily for their own ultimate benefit and comfort. The fox in his lair, the mole in his communicating trenches, the squirrel in the tree trunk, the mouse in his nest, all know that it is the setting of a scene that has grown to be a part of their very lives, without which they would find winter unendurable, and they watch its progress in content from within their snug retreats. When all is over they will [85 ] 


\section{In Winter Quarters}

sally forth, and the boy who loves woodcraft will then find occupation a-plenty studying the dainty traces of their wanderings through the freshly fallen snow. But the virgin snow is a great betrayer of the forest creature's secrets. The tiniest bird or beast that sets foot upon the delicate surface advertises that which it would fain conceal. The writings of these folk on the snow are easily deciphered by their enemies, as well as by their friends.

There is nothing finer in the world than tramping the woods after a heavy snowfall has obliterated all the roadways, paths and trails; provided you only think so; provided you have still some of the primal instincts left in your system after civilization has done its worst for you; provided always you are properly dressed for the adventure. Next to this I used to like a horseback ride through a heavy rain-if "slicker" and leggings were available. Rain-in- 


\section{When Snows Are Deep}

the-Face was a great Sioux warrior. I always liked his name. We may be distantly related for all I know. Somewhere back in ante-diluvian days we may have hunted together in the misty hills. I rather think we did.

Longfellow's despairing delineation of the "cold and cruel winter" in "The Song of Hiawatha" is one of the glories of our literature, but it was written to fit "the famine and the fever"; and that is getting back to our original proposition. The season is a joy or a curse just according as you happen to be physically and mentally situated. There is little or no real distress in this latitude on or about the farmsteads of those who have been wise enough to resist the call to city flats. The average farmer not only provides himself and family with all the needed comforts, but, more than that, looks after the well-being also of the animals that constitute such an essential factor in the agricultural 


\section{In Winter Quarters}

economy of the day. This is not only the part of wisdom from the standpoint of dollars and cents, but is a fine confession of the moral responsibility actually assumed by those who have developed through clever manipulation races and types of domesticated animal life, admirably adapted to serve a useful purpose, but demanding help if they are to survive rigors with which they are unfitted to cope. Those forms of animal life which man has not tried his 'prentice hand upon need no coddling.

If you are breeding buffaloes or beavers you need not bother about barns or good warm basements. You can sit by your own fireside and take no heed of whatever the thermometer is doing. But with your Jersey cow or Southdown ewe, the case is different. Minnesota is not a Channel Island, and the Laramie Plains have somewhat more exacting Januarys than Kent or Devonshire. Hence if you will insist 


\section{When Snows Are Deep}

upon transplanting products of Gulf Stream environments into the northern United States or Canada you have no business to ask them to hug the leeside of a barbed wire fence on a stormy winter's night. And so with our friend the harmless necessary hen. If you are breeding owls, then leave them to their own resources. Never fear. Nature will look after her own all right. That proud rooster though that strutted and flirted his way so gaily through the fields and gardens last summer will be a sorry specimen by February if not given real protection from the frost. He doesn't look well and loses all his cockiness if that bright red head-piece of his is blighted and blackened by being frozen. His best "biddy" will scarcely look at him.

Fine poultry, like fine cattle and the fleecy flocks, are artificial products of man's own ingenuity, and he must help them when they are helpless, or [89] 


\section{In Winter Quarters}

Nature will either destroy or modify them to conform to her own all-wise notions of what a bird or beast should be to survive her not always tender handling. Knowing as we do that in many cases these creatures are owned by men who expect them to shift more or less for themselves, I never see a bitter winter night settling down over our iron-bound territory that I am not oppressed by the certainty that somewhere not only poorly-protected humans, but thousands of other living things, are facing sufferings intense; and this feeling detracts always from the satisfactions waiting round the glow of the evening lamp, as the icepond in the park begins to crack with cold and darkness overtakes alike both sheltered and unsheltered flesh and blood.

Being snow-bound has no terrors for those who love good books or those who find something more than heat in the open fire-place. Strange, isn't 


\section{When Snows are Deep}

it, how universally we are led back to the trees? Even the steam that we are just now relying on for our own winter's comfort speaks of the coal measures where the buried forests of forgotten ages wait the summons to give back the fires of Nature's yesterday. And you who have the big fat back-log of more recent growth and the drift-wood, birch, pitch pine or heart of oak or hickory to feed it with have established actual touch with the golden days of youth, the out-of-doors and all its blessings. The log that beams for you tonight once bore aloft the swaying cribs in which wild birds were cradled, the lofty branches through which the breezes of the summer night once wandered underneath the stars.

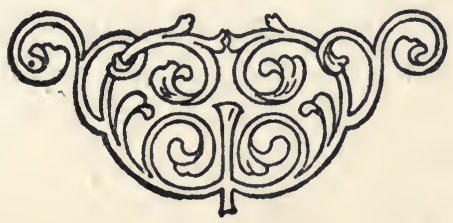

- [ 9I ] 



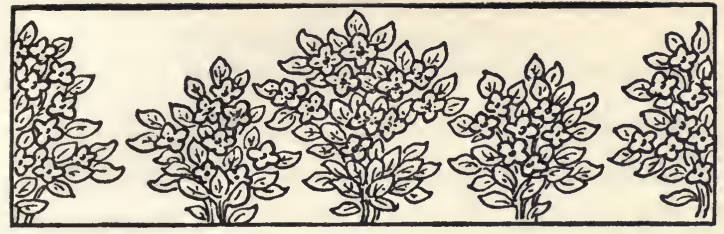

\section{VIII}

Parkways and Willows

\INTER has apparently suffered a relapse, to be more than made good no doubt during March and April. Meantime the very breath of spring is in the atmosphere. Green grass and a sky of blue add to the delusion of the hour. Along the boulevard the motors whirl their loads of human freight. Milady prefers an afternoon at bridge, the matinee or Field's. The downtown clubs will be filled with men and smoke. At the Athletic they will still be unreconciled to the awful drouth, and play their Kelly pool. Down street a little farther, at the Chicago Club, a select few are seated at the front windows viewing the passing show [ 93 ] 


\section{In Winter Quarters}

upon the crowded avenue. Over at the Union League a proper lot of highly respectable citizens will lounge about, talk business, golf and gout, discuss civic health and morals, read the early afternoon editions and consume perfectos. At the Blackstone elaborate luncheons will kill the better part of what is really a perfect day outdoors. The Board of Trade and Stock Exchange will close in time to permit the gamblers to loiter around "the street" an hour or two discussing May corn or U. S. Steel. Toward night machines and trolleys, trains and busses, vehicles of high and low degree in one vast concourse will essay the task of transferring 300,000 people, who think they have been doing something or enjoying themselves, from the downtown inferno to their respective caves from three to thirty miles distant, and the traffic police will have their hands full managing the riot.

I have been one of this self-same [94] 


\section{Parkways and Willows}

crowd, and am familiar with its ways. I have perhaps done my share of work along conventional lines. Have burned midnight oil at home on copy which the printers had to have next day. Have stood over the stones and galleys with an old foreman-long since gone to his reward-making-up forms for presses that were waiting to receive them, as late as 4:00 A.m. I have thought it incumbent upon me to hoe and hoe persistently through all these years for place and means to support a manner of living that differs decidedly-and I am not sure but for the worse-from that still happily adhered to in the South Sea Isles. I have "conformed" in other words, including lobster salads; and as one result any Cossack in a wolf-skin jacket on the Russian steppes has me physically beaten eighteen miles.

One gets more oxygen working before the mast around the Horn or riding a bronco on the western range than from the bituminous clouds that envelop [95 ] 


\section{In Winter Quarters}

the corner of South Dearborn and Harrison streets. The city man is putting an ounce of carbon into his system for every extra dollar in cash put into his purse. I am like most of the rest of you. I have put in too much time working for landlords, grocers and department stores, and not enough in acquiring knowledge of grasshoppers. I have thought in my folly I was doing something perhaps worth while by undertaking public service when I had better been out upon the hills with a good Collie dog. There can be no particular satisfaction, I imagine, trying to listen to the hum of bees amidst the clover blossoms that grow above one's head.

Abandoning our friends, for a little time now to their respective vices and vocations downtown, perhaps my overcoat and hat may lead me even here in Lincoln Park to new and real experiences. I never took a walk or a ride in my life where I could establish 
touch with things worth looking at that I have not returned more than ever satisfied that the whole universe is kin, and that we know nothing at all about it. This afternoon, at this season of the year, there will be little of bird, of flower or insect life abroad, but can't you hear the water lapping softly the sandy shores of that lagoon? Go rather to the "movies" if you like! And that great bank of cloud drifting yonder down the lake! It came from I know not where, and is floating lazily towards the distant port of "Idon't-care." Follow the crowd down State Street if you prefer. I shall not. And that word "crowd" tells the whole story. I can enjoy a herd of Herefords or a flock of Shropshires, but mobs of mere people I prefer to avoid! There is no congestion of men or women therefore where I commonly walk. That is, if I have any choice in the matter.

Speaking of statues, there are many

[ 97 ] 


\section{In Winter Quarters}

cast in bronze sitting or standing or riding around here in the park. I don't think tourists travel overseas to see any of them. Saint Gaudens' Lincoln is a truly noble conception, and lends dignity to this entire section of the city, but I am not so sure of the equestrian Grant and half-a-dozen others. There is one thing though in respect to these monuments for which I am duly grateful. The two that I have to live with are Linné and Shakespeare. I might have landed in an apartment facing the park farther to the north and had to look willy-nilly at that monstrous Goethe. So all is not hopeless. I really do not know whether the heroic figure of the great Swedish naturalist is art or not. I have my suspicions. But just the same I love to go over there and visit with him. He stands in a bosky bend of the driveway but a few hundred yards from our window, and is to me a constant reminder of woodlands wild and [ 98 ] 


\section{Parkways and Willows}

fields, of moors and mountain slopes where plant-folk bide. How well he knew them, each great or humble dweller in his kingdom, and how gladly they yielded up to him their inmost secrets! I never go over there and look up into his face without wishing that I too knew something of sepals, stigmas, bracts and fronds and pollens. And yet what a comfort it is to understand that one after all does not have to be a learned scientist to feel and know the beauty of a "murmuring pine!" Any of us can grasp that joy if we have but eyes to see and ears to hear; if we but look up with Perseus, not down with pugilists.

It seems to me that if I were a sculptor and had received a commission to execute a statue of a man who has a great name and character to sustain before the world, and the man according to all traditions was bald as a hornet, and the monument was to be set up out-of-doors somewhere in 


\section{In Winter Quarters}

this latitude, I would hesitate a long time before seating him bare-headed and all "dolled up" in full drawingroom costume. This is what happened to our dear old bard of Avon in Lincoln Park. It is true that few people ever stop to note his plight when rains or snows are beating on that big Shakespearean dome. The statue is really most admirable as a fair weather proposition, but with one eye and both ears plastered full of wet snow, and an inch or two of "the beautiful" resting where hair or hat should have been, I can assure you it is hard for anybody, however great, to look specially dignified or really serious.

I do not know how much or how little the sense of humor is developed in my own particular case, but I do know that "the myriad-minded" once assumed such a truly fearful and wonderful expression as a result of the storm king's pranks that I grinned in spite of myself when I saw the liberties

$$
\text { [ roo ] }
$$





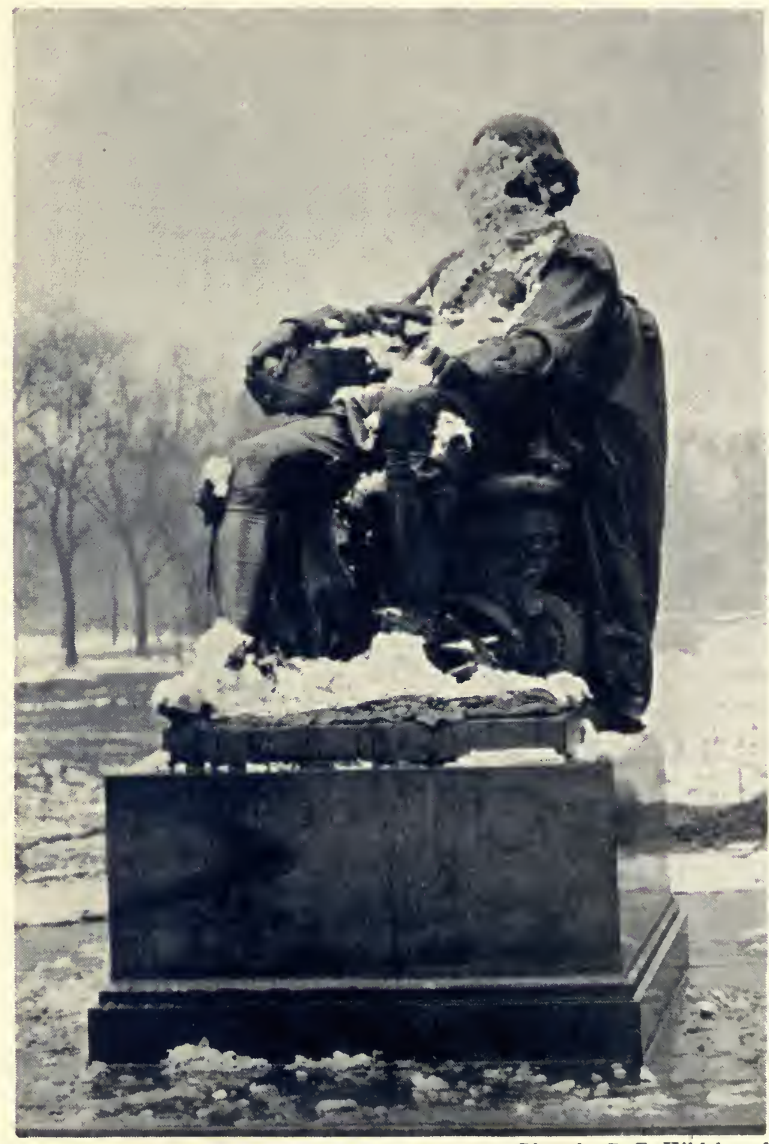

Photo by R. F. Hildebrand

"What a Piece of Work is Man"-Hamlet 


\section{Parkways and Willows}

old Boreas had taken with the creator of Hamlet and Macbeth. And, again, one other day when weeping skies were wrapping all the landscape round about in mist and rain poor William was again put to it hard to retain his grip upon our self-restraint in his awesome presence. He sits there in knee breeches in a "comfy" chair; his bronze silk hose tied up with big bow-knots. Perhaps I should have too much respect for him who gave the world Othello and King Lear to tell you that great drops were falling from the Jovian beak down his ruffled shirt-front into the divine lap, attaining the dignity of real rivulets by the time the toe of the extended sacred foot was reached. Even so, thought I, once flowed the fountains of his genius, and then I smiled again at the amusing picture of a shower bath in dress clothes in a public place. But come to think of it why indeed should not the statue now and then bring the laughter that [ IOI ] 
always lies so near the tears? Have we so soon forgotten Sir Tobey and the Dromios? Why not therefore high comedy as well as great romance and tragedy effectively dispensed at different hours and seasons from the selfsame monument?

And while on this subject, many of you have seen of course the famous Lafayette group of statuary opposite the White House grounds in Washington. The marquis high upon his pedestal with a flowing drapery depending from an extended arm looks down upon a female figure placed in supplicating posture at his feet. The lady looks up appealingly into the hero's face and holds aloft for him to grasp a sword. America pleading for his help perhaps; but once upon a time a sacrilegious wag remarked, after studying the situation, that the woman is really giving expression to a very elemental human thought: "I say, old Top, please hand me down my 


\section{Parkways and Willows}

clothes and you shall have your blade!' How short indeed the step at times from sky to earth! History, however, records the fact that the marquis actually took the sword and wielded it with true Gallic brilliancy in our behalf, and not many months ago Pershing stood at a grave in the little Picpus cemetery in the eastern environs of Paris, and made the most eloquent speech as yet evoked by the great world war. With uncovered head the American commander simply said: "Lafayette! We are here!" I know the spot; and if I remember right, just outside the cemetery gate is a little church, or convent, with a chapel, where the tapers ever burn, presided over by the sisters of the Order of the Perpetual Adoration. And even as that altar is never deserted for a moment night or day, so must we guard with like devotion the sacred fires of liberties now menaced-not from without, but from within.

$$
\text { [ } 103 \text { ] }
$$




\section{In Winter Quarters}

There goes a nursemaid with a little girl by her side and a toy dog trying to act like a real one. Of course he can't. But that is not his fault. He was bred that shape and can't help himself any more than I can change the convolutions of the cerebrum and cerebellum which several million different individuals conspired to hand to me. You see we are all in the same boat. There is no escaping some things. Each man, each Dachshund, "cootie" or canary is but an unwilling composite of a couple of billion other creatures gone before, having had no more to do with the mixing of his own ingredients than Beethoven had to do with the modelling of that bust on the pedestal yonder that bears his name. The bust has certain great advantages, however, over the rest of us. For one thing it doesn't have to sit through the gruesome glories of the "Goetterdammerung," but gets real thunder and the lightning's brilliant play from

$$
\text { [ } 104 \text { ] }
$$




\section{Parkways and Willows}

clouds first-hand. Perched there in sunshine and in storm, in fixed complacency complete, it mocks the petty pageant of the passing world, agreeing perfectly no doubt with Puck"What fools these mortals be!"

A seedy-looking individual who looks as if life had not been altogether kind is wandering down the gravel walk ahead. His clothes may have appeared very "smart" once upon a time draped on a form in a store priding itself upon handling the goods of say the house of Hochenheimer, but they are not nearly as good-looking now as the suit that pup is wearing. Moreover, I don't believe our friend is specially interested either in the lapping water to which I have recently referred as being worth studying. I spot him as just a human derelict, and seeing that I myself am practically alone here amidst these same grateful surroundings, far off the beaten track being pursued by nearly all my friends and 


\section{In Winter Quarters}

acquaintances this same afternoon, I am not sure but the term is more or less applicable to others than the hobo who makes no secret of his status in the social scale. Still I am not yet quite an abandoned craft, for sometimes I fetch myself sharply about and find real satisfaction in a course squared with the regularly charted lanes of human travel.

I note one other point of divergence between poor "weary 'William" and myself. He has gone straight by the finest tree I know in this whole forest, and never even so much as gave it a casual glance. That is to me little less than criminal. Let us make up for his boorishness therefore in that particular by paying our respects before we pass. It is a member of the willow tribe, and on its hoary trunk there is a rusted label, evidently tacked there years ago by order of some park superintendent who had some adequate appreciation of the duties of his posi[ 106 ] 
tion. The inscription is almost obliterated now, but a glass enables me to read "Salix Alba!" So let the shifting currents bear our world-worn brother where they will. May angels somewhere take his case in gentle hands! I can't. I want to know more about this Salix business.

If by chance you are interested in trees possessing character, pronounced individuality, picturesque personality, just run up some day to the point where the great Chicago fire of 1871 finally burned itself out at Fullerton Parkway. Here in the most beautiful residence section of the city, to my way of thinking, at the present time, you will find not only Salix Alba but Salix Nigra as well; rare old specimens of both varieties. Maybe you do not know them by their stage names, but you will admire and quickly recognize them as splendid, venerable willows, white and black, seamed and scarred from years of battling with 


\section{In Winter Quarters}

the elements; more attractive even in their winter dishabille than when they later don their catkins and lanceolated foliage. The Salix outfit may not contribute much to the lumber yard stocks of the country, but they do give us charcoal and look well either alive or when blazing on a pair of andirons; and the alba, a European importation, with age develops a girth and shagginess that make it a distinguished figure in any wood in which it may be found. It gnarls and knots and besprouts its various excrescences in a way that should get the eyes of artists. There are plenty of them in this neighborhood-willows, I mean; not our friends of the Van Dyke beards who smoke old pipes and wear long linen "dusters" in their studios. A good one standing just opposite my study window has a hollow trunk that is a favorite refuge for the squirrels when stray dogs send them scampering up aloft with furiously-beating hearts. 


\section{Parkways and Willows}

Much as I love these shaggy old albas, the nigras with their diverging trunks are a source of even more delight. I have always been fond of trees having the multiple-body habit, which is characteristic of the yellow or Golden Osier willow, as well as of the black. The osier, however, is not so common here in the west, and I once consulted the famous tree expert Romeyn B. Hough as to its foliage, so that I might not fail to recognize one if by chance $I$ came upon it during the early spring or summer months, and this was his reply. I did not know before that such a simple question in reference to such dainty growths could call forth such an explosion, and will quote verbatim et literatim for the benefit mainly of any little ones who may wish to get on familiar terms with the yellow willow's plumage:

"LEAVES lanceolate, 2-5 in. long, tapering to base, long acuminate, finely serrate, silky hairy both sides when young, glabrous at maturity and dark green above, paler and [ 109 ] 


\section{In Winter Quarters}

glaucous beneath; stipules ovate-lanceolate, deciduous; petioles $1 / 3$ in. long or less, slightly if at all glandular; branchlets glabrous, bright yellow or reddish tinted. FLOWERS appearing with the leaves, aments terminating lateral leafy branchlets, scales yellowish, falling before the ripening of the fruit; stigmas nearly sessile. FRUITS capsules narrow-avoid, long-pointed, glabrous, with very short pedicel."

So you see all you have to do to determine whether you are looking at a real Golden Osier or some other willowy creation is to note carefully as to whether or not the leaves are both acuminate and serrate, and glabrous as well as glaucous underneath, and that the stipules are ovate-lanceolate! But whatever you do don't forget to observe whether or not the petioles are slightly glandular. The aments you will know all about, for that is only the botanist's playful way of naming catkins. The thing that interested me most, I remember, at the time I conferred with the author of "American Woods" and the "Handbook of [ IIO ] 


\section{Parkways and Willows}

the Trees" concerning these old-world willows was to learn about their "fruit." I just dote on long-pointed, narrow-ovoid capsuled fruits; especially if they be glabrous! Don't you? And when you make certain that the pedicel is short, then you will begin to suspect that you are at last face to face with the real Salix Vitellina. Before committing yourself positively, however, it may be just as well to look for those nearly-sessile stigmas, and if these measure up to specifications you need only bear in mind further that the Golden Osier shows a fine bright yellow when the sap begins to rise; and that it has a short thick trunk sometimes as much as five feet in diameter at the base, which divides at or near the ground into various sturdy branches.

To see old black and yellow willows at their best you should approach them from the water-side. You may find them inland of course, but they are happiest with their feet in a gently- 
flowing stream, in some quiet pool or park lagoon. I know one of these made up of ten separate distinct trees, all radiated from the same root-nest, and these associated trunks do not grow erect, but lean far out across the water or stretch themselves lovingly above the turf that decks the shoreline of a little lake. And within their sheltering embrace may be found that which cannot be bought on Broadway, and does not exist at all in Fifth Avenue.

I suppose ten thousand automobiles go rushing by the Matthew Laflin Memorial building in the park every day. Now and then some vagrant like myself, on the lookout for something not to be seen in city streets, drops in. Once in a long while a machine may turn off the main drive and its occupants enter the halls where the Academy of Sciences under Frank M. Woodruff's able direction is doing so much to recall the pristine glories of the marshes, dunes and woodlands of pre-historic [ II2 ] 


\section{Parkways and Willows}

Chicago. The children fortunately come in schools to rave over the wonderful habitat settings of birds and beasts and bugs and flowers there presented. Beginning with the sand dunes at the lower end of the lake-with real sand from the dunes, real driftwood from the beach, and mounted specimens of nearly every form of wild life known to have inhabited that still untamed wilderness, and with a marvelously-wrought-out panoramic background perfecting the illusion of the scene, the wild life of early Chicago's environs will here have adequate and altogether admirable presentation. Passing from the dunes to the Calumet region the open channels and the reedy recesses dear to the water-fowl of the early days are shown with an almost startling fidelity to Nature. Thence the panorama is to lead one through the woods and streams and prairies lying to the westward of the great city, and on around through the oaks and 


\section{In Winter Quarters}

sands of the old North Shore back to the lake again. When the comprehensive scheme is brought to its completion, one of the finest exhibits of its character in the country will have been installed for the benefit of future generations. The present one shows a lot more interest in paved streets and granite skyscrapers than in the dry leaves and rocks and underbrush where foxes, wolves and weasels once had winter quarters.

Overhead the eagles, geese and owls, the ducks and terns and hawks, and all the feathered generations that once dwelled roundabout Chicago's site, suspended from long wires, are in full flight-true to life. Most Chicagoans at present, however, are more interested in the flight of oil and motor stocks, and the soaring quotations for shoes and sugar. However, there will always be a few who will find these splendid reproductions of native swamp and field and forest scenes a source of 


\section{Parkways and Willows}

profitable reflection and contemplation-recalling to those whose temperament responds at all to such vivid appeals, the wealth of freedom that has been lost in the onward rush of civilization. But the dunes still hold much of their virgin character. There the fox still is trapped within sight of steel-mill smoke, and the heron and the owl sweep down the sands as when this weird wilderness was young.

I am in favor of knocking down that behemoth or Goliath of Lincoln Park statuary known as Goethe, and substituting bronzes of Earl Reed, the poet-artist and Woodruff, the facsimile reproducer of the dunes. Why is it people don't know enough to duly honor their own worthy ones? I know of a presentation copy of the first edition of "Vanity Fair" to the Marchioness of Normanby, with an original drawing by Thackeray of Mr. Punch presenting a copy of his book, that can be bought for $\$ \mathbf{1}, 200$. Well, you may 


\section{In Winter Quarters}

buy it if you like, but I would certainly not think of exchanging for it, on even terms-so far as my personal interest in the subject matter is concerned-a copy of the first edition of "The Dune Country," with an original pencil sketch upon the title page entitled, "A bit of Michigan Shore," with its inscription, "Drawn for Mr. and Mrs. Alvin $H$. Sanders at the request of my friend Mrs. French, Apr. 6, 'I7," and autographed, "Earl H. Reed."

On some occasion I remember to have received a birthday or other anniversary card, carrying this sentiment: "I love you because you love the things that I love." All of which turns my thoughts back to "A week on the Concord and Merrimac rivers," with my favorite companion Henry D. Thoreau, and as he discourses upon Friendship I hear him say: "As I love nature, as I love singing birds and gleaming stubble, and flowing rivers and morning and evening, and summer and winter, I love thee, my Friend." 


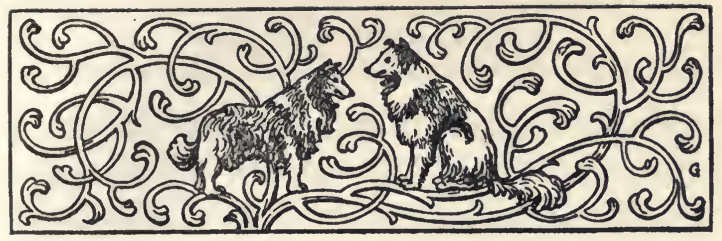

IX

Behind Iron Bars

THERE are certain other friends I I should like to have you meet. They may amuse or entertain you well, but I had much rather have you say that they excite your pity or compassion when you see them. They are of the animal not the vegetable kingdom; so if you prefer to go downtown and sit in the Pompeian room and study the human "zoo," all well and good. I have no objections. Every one to his taste. In that case I will go alone, as usual, to speak a sympathetic word to those behind iron bars. I have come to know most of them, not by any individual names, but by their respective personalities and peculiar- 


\section{In Winter Quarters}

ities; and there are as many different natures, as many varied moods, as many diverse types to be discovered inside these cages as you will find within the walls of human habitation. Eat, drink, pace up and down-then sleep! That is the captive's lot. And any experienced prisoner will tell you that the greatest of these is sleep!

I never look down into those bearpits, and the adjacent enclosures where the foxes, wolves and coyotes hold their court, without thinking of a sight I once saw inside a penitentiary. Only here in these pits the poor devils are all in for the full term of their natural (or rather, I should say, unnatural) lives, and against such a sentence of course no credit whatsoever for good behavior runs. And their only offense is that they were born subject to this man-handling of their respective destinies.

How to be happy though hopeless! That is a problem successfully solved, 
I imagine, by mighty few people in this world; and a more or less intimate acquaintance with the birds and beasts on view in the collection housed within a stone's throw of our own front door brings out once again the thought that after all there is no great difference, when it comes to the joys and sorrows of mere physical existence, between men and other animals.

So far as I have been able to discover through numerous visits, there are but two or three specimens in this particular assemblage, gathered from the ends of the earth, that do not seem to care a rap about confinement. There is a "roly-poly" grizzly that is obviously happy. He is a living picture of contentment. He finds the peanuts flung into his cage exactly to his liking. If you stop and do not toss him one, he is very apt to sit up on his haunches, and give the "high sign" of his expectation. And if you throw his way the morsel he so dearly loves you can rest [ II9] 
assured he will catch it as unerringly as a crack first-baseman gets a ball hot from the pitcher's box. And how he reveled in the snow that fell just before the Christmas holidays! Over and over he rolled, twisting and turning in his thick fur overcoat. A soup bone he had previously cleaned caught the ursine comedian's fancy. Flat on his broad fat back he grabs it and begins real Japanese juggling stunts. Balancing the bone upon his paws he throws it in the air, catches it as it falls, laughing heartily at his own clumsy cleverness. A black bear next door is copying friend grizzly's peanutbegging tactics, but has not the merry twinkle in his eye, the sheer good nature that radiates always from his Rocky Mountain brother.

Apropos of the snow, the polars actually were half-way comfortable for a time while the blizzard raged. Sprawled out on their "tummies" with legs extended fore and aft so that 


\section{Behind Iron Bars}

they might get their bodies in closer contact with the cold they miss so much, these wretched convicts had actually a few really wonderful moments. They have dens in the rear of their open-air compartment where they are supposed to pass the night, and while the snow was falling fast they took occasion to paw and scrape quantities of it into their sleeping quarters. Yes, it is an ill wind that blows nobody good!

I wonder why it is that these products of the frozen North are white? We do not think of wearing white flannels during the winter months here in our latitude. Dark, rich colors seem to meet the human idea of suitability for zero weather conditions. Come to think of it though men-folk born considerable distances from the equator do wear white-I mean in a state of nature. The black and bronze races appertain specially to lands of the sun. 


\section{In Winter Quarters}

It is because so many of the inmates of the "zoo" are natives of either torrid or frigid zones that their confinement here condemns them to much suffering. True, you can make that elephant and her neighbors the pythons and giraffe comfortable here in January with a sufficient steam pressure, and in the summer it gets quite hot enough to meet their inborn notions of climate out-of-doors. But white bears have no escape from our Ioo degree dog-day torments. So I figure that they are worse off here than anybody else. And they look it, and act it. They are sure-enough neurasthenics. To watch them going through that endless forward-and-back, side stepping, head-tossing performance for any great length of time almost gives me "the willies." I should like to see them-at safe distance-in their own possessions, the snowy wilderness and floating bergs, but in Lincoln Park accommodations during August I can't 



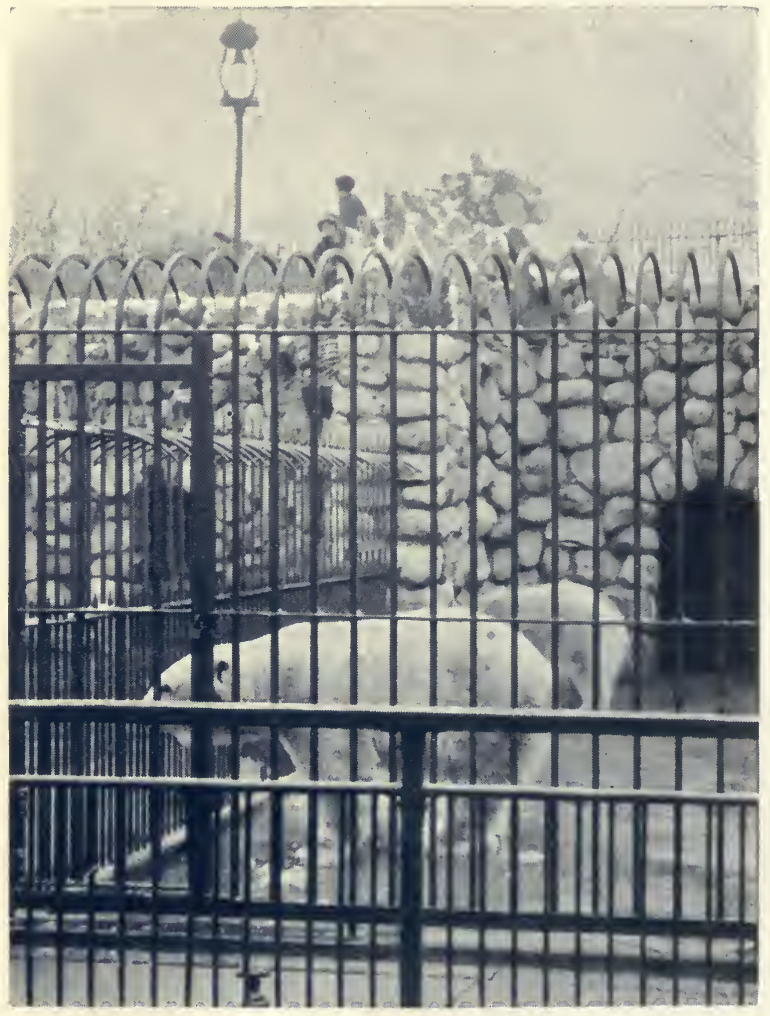

Photo by R.F. Hildebrand

Home Was Never Like This 


\section{Behind Iron Bars}

see how they appeal to anybody. And now you big game hunters and all others who find "sport" or pleasure or satisfaction or something else in killing, not for food, but in cold blood, creatures having the same right to live that you claim for yourself, I insist upon a reading of the following from the pen of John Muir, the famous explorer of wild places, mountaineer, geologist and fascinating writer. And I want you to read it to the very last sentence. It may be found in "The Cruise of the Corwin:"

"The grand excitement of the day, apart from the untrodden shore we were seeking, was caused by three polar bears, magnificent fellows, fat and hearty, rejoicing in their strength out here in the bosom of the icy wilderness. When discovered, they were regarding us attentively from a large cake of ice, each on a hummock commanding a good view of the ship, an object they no doubt saw for the first time in their lives. One of them was perched on top of a pile of blocks, the topmost of which was a pedestal square and level as if built up 


\section{In Winter Quarters}

for an outlook. He sat erect and, as he was nearly the color of the ice, was not noticed until we were quite near. They watched, motionless for some time, throwing forward their long necks and black-tipped noses as if trying to catch and pass judgment on the scent of the big, smoking, black monster that was approaching them.

"When we were within about fifty yards of them, they started, walked a step or two, and turned to gaze again as the strange object came nearer. Then they showed fear and began to lumber along over and across the wavelike rough hills and dales of the ice, afraid, perhaps, for the first time in their lives. For polar bears are the master existences of these frozen regions, the walruses being no match for them. First they broke into a lumbering trot; then, into a panicky, walloppy gallop, with fewer and fewer halts to look back, until they reached the far side of the ice-field and plunged into the water with a splash that sent the spray ten feet into the air. Then they swam; making all haste towards a larger floe. If they could have gained it they would have made good their retreat. But the steamer gave chase at the rate of seven knots an hour, headed them off, and all were shot without the least chance of 


\section{Behind Iron Bars}

escape, and without their being able to offer the slightest resistance.

"The first one overtaken was killed instantly at the second shot, which passed through the brain. The other two were fired at by five fun-, fur-, and fame-seekers, with heavy breech-loading rifles, about forty times ere they were killed. From four to six bullets passed through their necks and shoulders before the last through the brain put an end to their agony. The brain is small and not easily penetrated, except from the side of the head, while their bodies may be shot through and through a score of times, apparently, without disabling them for fighting or swimming. When a bullet went through the neck, they would simply shake their heads without making any sort of outcry, the effect being simply to hasten their flight. The same was true of most other wounds. But occasionally, when struck in the spine, or shoulder, the pain would make them roar, and groan, and turn to examine the spot, or to snap at the wound as if seeking an enemy. They would dive occasionally, and swim under water a few yards. But, being out of breath, they were always compelled to come up in a minute or so. They had no chance whatever for their lives, and the whole affair was as safe and 


\section{In Winter Quarters}

easy a butchery as shooting cows in a barnyard from the roof of the barn. It was prolonged, bloody agony, as clumsily and heartlessly inflicted as it could well be, except in the case of the first, which never knew what hurt him.

"The Eskimos hunt and kill them for food, going out to meet them on the ice with spears and dogs. This is merely one savage living on another. But how civilized people, seeking for heavens and angels and millenniums, and the reign of universal peace and love, can enjoy this red, brutal amusement, is not so easily accounted for. Such soft, fuzzy, sentimental aspirations, and the frame of mind that can reap giggling, jolly pleasure from the blood and agony and death of these fine animals, with their humanlike groans, are too devilish for anything but hell. Of all the animals man is at once the worst and the best.

"Two of the bears were hoisted on board, the other was neglected until it could not be found. Then came the vulgar business of skinning and throwing the mangled carcasses back into the clean blue water among the ice. The skins were stretched on frames to be dried and taken home to show angelic sweethearts the evidence of pluck and daring."

[ 126 ] 


\section{Behind Iron Bars}

There is an Eskimo dog in one of the runways that divides with the fat grizzly already mentioned the honor of being quite resigned to his job, only he never really knew what freedom is. He has escaped the drudgery that falls to the lot of his former canine comrades in the sledge-hauling business, and he knows it. You will see him usually with a real smile upon his friendly face, and he often romps and waves his upcurved bushy tail in absolutely infectious glee. A favorite pastime in his case is racing up and down a high partition fence, barking and snarling savagely in mock-heroic combat with a big grey wolf next door, pretending that he is just dying to sink his fangs in the lupine throat, and "brer wolf" goes to the sport as if he really meant business. Together they tear frantically through this impossible finishfight; the only difference being that the wolf seems to take it seriously and is really spoiling for the fray, whereas 


\section{In Winter Quarters}

the dog is only bluffing and doesn't care who knows it. Lots of folks are good at that same sort of game, when it is equally safe to play it.

The members of the coyote pack have not forgotten how to howl. Three or four times a day, and always once in the early morning hours, they join in the shrill staccato chorus that may be heard for blocks, bringing the weird music of the foothills and the plains to our very doors. I never tire of that. It calls to something somewhere deep down in my nature. Why is it? Why do those short, sharp notes, rising and falling in savage cadence, bring a never failing response? I should have been born and should have lived I suppose where that challenge would have had a deeper meaning. Thus are the primordial instincts of the cave preserved and handed down by the subtle force of heredity through all the generations. And I have a stone hammer I once found in the Black Hills country that 
I often take in my hand and feel at home with it.

One of these coyotes looks as if he might be quite amenable to human influences, and would not resent human companionship. I have no doubt he has killed more than one innocent lamb out on the range, for I know his taste for that form of food. But he is an amiable-looking rascal and socially inclined. Moreover, he has the springiest, easiest, steadiest, most alluring trot I ever saw. I have certainly seen that self-same coyote once before. I can't just remember when or where; but he was jogging down a long, long, lonely trail, headed for the eternal hills where skies were blue and the air was as wine, and the world was spread before me in all its unspoiled glory!

Talk about "ruminating!" The most inveterate "chewers" I know are the bulls, cows, yearlings and two-yearolds comprising the buffalo herd. Too bad the carnivorous crowd have no 


\section{In Winter Quarters}

cuds. The habit seems so conducive to peace of mind. If those tigers, leopards, lions and other cats could only settle down and munch away on a little roll of something they might not be so dissatisfied and nervous.

The bisons were of course bred in captivity. They never saw the plains, prairies and Bad Lands of the West. They eat good hay and lie around the lot in stolid comfort, just as any other domesticated bovine would. They may dream sometimes of grassy unfenced worlds, but are much safer here from arrowheads and rifle-balls than were their free progenitors. Their architecture is not altogether understandable. I know that old bull's head outweighs his body. His front and rear do not seem to match. His hindquarters would pass through a goodsized crack in a barn-door, but you would have to knock out the whole end of the building to get his shoulders in. I don't see how he could gallop

$$
\text { [130] }
$$


through the sage brush and the cactus without turning somersaults every fifteen feet from lack of proper counterpoise. But his grandsire could, and did.

The buffalo calves are cute little runts. Look at that one alongside the woven wire fence with his nose poked through the open mesh licking the lips of a great ungainly Siberian camel that seems to enjoy the lingual buffalonian caress. An exchange of amenities between the Occident and Orient is obviously in progress; a situation rather more pacific in its aspects truly than that projected in the shadow of these fateful League-of-Nations days. The particular Asiatic of which I speak has a self-satisfied look upon his docile countenance, but how he endures the swaying of those two enormous humps of fat that threaten to topple off his back every time he moves is something hard to comprehend. And that great siphoned neck in cultured camel circles 


\section{In Winter Quarters}

is no doubt considered graceful beyond the wildest of all desert dreams.

Do you know the Wapiti? Well, they are just elk. They are here also. Maybe from the great herd that roams the grand preserve men call the park of Yellowstone. They are clearly ready to go any time they can. A comely heifer wanders away to the farther corner of the yard, lifts up her fawnlike face, throws her big ears forward, looks yearningly in the far distance and gives utterance to a plaintive little cry; but the mountain meadows shall not know her hoof-prints.

You may like Simians. I do not. Monkeys, baboons and apes look and act too much like some humans I know, and am not crazy about. They are all busy these days in their nonetoo-well ventilated hothouse, bug-hunting as usual. A mother lovingly looks for "coots" on a baby breast; the darling child throwing up its head and protruding its throat and chest so that 
the maternal examination may be thorough. Let us hope it is. I have no quarrel with this lot, any more than I have with mice or other vermin! They can't help being here, nor being what they were born to be. I just don't care for them. That's all.

The giant cats are a moody lot, and the barometric pressure or something else seems to affect them all alikethat is to say, they are all in the same frame of mind apparently at the same time. They will either all be asleep, or all striding along the bars, or all playful, or all "sore" about something during the same hour. That pair of lion pups will play like kittens if they get any encouragement from the rest of the family, and I have seen old Father Leo there in the corner cage-as fine a specimen of the real Numidian monarch as you are apt to find in all Africa-have a lot of fun with a younger brother in the adjacent box. He was holding his big joint of raw 


\section{In Winter Quarters}

beef down between his paws and crunching it as easily as if it were a tenderloin, when suddenly he thought of teasing his next door neighbor with it. Leaping upon the shelf against the rear wall of his den, he jams the joint of beef against the steel rods that separate him from Leo Jr., and dares him touch it. The latter pretends to accept the defiance, and with a bellow that fairly shakes the solid building the big boss jerks the bone away, rolls over and down and looks royally well pleased at his little joke; and incidentally there can be no sound in all this world more paralyzing in its effect upon human ears than this great lion's thunderous throaty roar reverberating throughout the length and breadth of that high-roofed space enclosed in brick and steel.

Restlessness frequently pervades the really beautiful interior of the house of lions. The tiger's fearsome yell resounds throughout the hall that fits so 
well the dignity of the forest monarchs there interned. The savage Bengal brutes with grinning mouths are leading the sad parade of all the demons of unrest. The lions now grown quarrelsome, snap at a keeper as he passes by. The panthers, too, reveal their fangs and call defiantly, and leopards swell the rising and falling fanfare of feline infelicity.

I have studied also that giraffe in his endless travels round and round his narrow stall. It is a "one-way street" with him. At least he is always going in the same direction; never reversing his course. As he makes his rounds he chews his cud, and now and then stops, with his head of course up there somewhere near the roof, to contemplate the scene below. Aviators of the upper air haven't much on him as observaticnists. He hasn't a great big brain box, and so far as I have been able to diagnose his mental state, does not seem to be worrying whether he is 


\section{In Winter Quarters}

going or coming. His front and rear have even less in common than that buffalo bull we saw a while ago. However, such small matters as relative physical conformations are of no real consequence to any of us because there are no common standards of comparison. The giraffe unquestionably looks down upon man as a mere freak of nature; his own make-up being from his standpoint the one and only correct anatomical construction. The question in all cases is not whose leg is the longest or biggest, whose girth greatest, or whose-feet are cloven or webbed. The real query is: what sort of spirit dwells within? In human-kind, is it that of Perseus or pugilist? And if I had my way there would be no prison pens for living birds or beasts in Lincoln Park or any other. Museums and taxidermists are bad enough.

Meantime, what is the lesson of the "zoo"? Most of you will say perhaps [136] 


\section{Behind Iron Bars}

that it is to be found in the case of the happy grizzly. That the restless, fretting creatures all around are only committing slow but certain suicide. Unfortunately perhaps the eagles and the mountain lions of this world do not yield their freedom easily. Set not up therefore for their guidance the picture of the bison basking and blinking in the sun! All creatures cannot find content complete in chewing forever only "the cud of sweet and bitter fancy."

Some are too highly organized for that. Some cannot be satisfied with a life of mere peanut-catching or playing day by day with just an old dry bone. Some require a little more than thator think they do. Expect not therefore the deer to forget his native forest haunts. Know that the keen red fox will remember to his dying day his silent moors and stony hills. Tell not the mallard to stop dreaming of wild rice and open water. And there is ambition's kindred call in human 


\section{In Winter Quarters}

breasts. Are those who know and love the higher trails of this existence to be content with just the bread and meat that hold body and soul together overnight? For one, I glory in that Bengal tiger's stout refusal to be reconciled. He does not know of course that o'er the door is written as to him, "Abandon hope all ye who enter here." And it is well that he is in such blessed ignorance of that fact. For if he knew the truth he probably would not try. So in this daily protest of these captive beasts, waiting, watching always for the change they all agree is sure to come some day to them, we find anew the secret of the only way the worthwhile summits, each of his own career, are ever to be reached.

Not far away the big bronze Shakespeare sits and meditates. His face is ever toward the rising sun. Around about him I can always see the ghosts of his creations, and if you listen as you pass, it may be you will hear stout[138] 


\section{Behind Iron Bars}

hearted Richmond on the eve of Bosworth Field repeat:

"True hope is swift and flies with swallow's wings;

Kings it makes gods and meaner creatures kings."

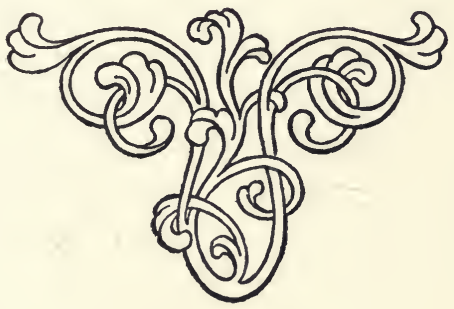





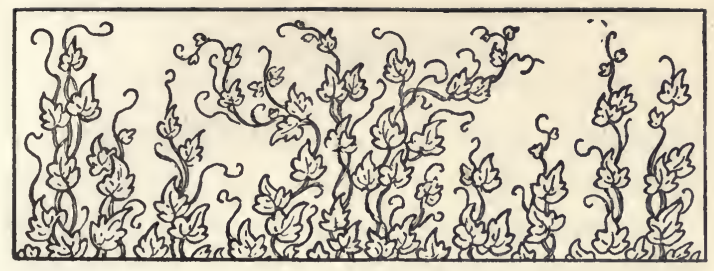

\section{$\mathrm{X}$}

\section{Compelling Chords}

TOBODY ever makes more than N two or three real sure-enough friends. Those who find more than one are rare, and are blessed accordingly. Many unfortunates have none. This is not necessarily because there is no one in existence possessing the qualities needed in the particular case, but rather because Fate has not decreed that two certain paths should cross. A dog may live for years before he chances to hear the one and only vibration that will force the inevitable howl. And maybe he will die before he ever hears the all-compelling note. But if it ever does fall upon the canine ear he is certain to recognize it in- 


\section{In Winter Quarters}

stantly, and be profoundly stirred thereby.

I once knew a dog that never had her voice forced by any chord or dischord whatsoever. You could try all sorts of harmonies or the reverse, test her out with all the minors, flats and sharps known to the scale without audible answer, but strangely enough this dog developed a most peculiar sensitiveness in relation to the Victrola's rendition of Journet's bassoprofundo solo from the first act of Meyerbeer's "Les Huguenots." From the very first time she heard it this Chow simply would not stand for it. You might play everything you had in the box but that, and she would sleep on undisturbed, but before the first measure of this particular composition could be reeled off the record she would look quickly up, extend her ears to make sure that she was not mistaken, and then slowly rise to her feet, and with tail at half-mast and dejection 


\section{Compelling Chords}

unutterable written all over her expressive countenance steal silently and with dignity away - not to return that evening. It always seemed to me that she departed rather in sorrow than in anger, but just what it was that so harrowed her unquestionably fine feelings-for she was an exceptionally well-bred dog-we were never able to fathom.

However, I did not set out to write of dogs, fond as I am of good ones. We can all make friends among them, and nowhere may fidelity sublimated be so frequently developed as in the case of the dog you have cared for, nursed and sheltered. The point is that if you are so fortunate as to meet the one or the two or the three individuals, as the case may be, who possess that which is perfectly keyed to your own spirit, you will know it just as unerringly as Fido realizes when his nerves are played upon by the singing of some one certain wire or string. And, on 


\section{In Winter Quarters}

the contrary, as in the strange case of Lady Chow, most of us seem to be endowed with some form of mental antennae with which we sense with equal assurance those who "make us tired;" just as the cat's whiskers warn her that the hole is not wide enough to admit the feline head.

As in real life, so in the book-shelves. Here, too, you will meet all manner of people. And here also you may be lucky enough to find somebody whose presence you can bear, and whose companionship, in some subtle irresistible way, brings something satisfying that you have perhaps previously sought without finding. When you strike the real thing that comes straight home you will need no telling. You will recognize the work at once as really your own. The thoughts are exactly your own thoughts. How did the writer happen to know your own mind so perfectly? The ideas expressed are by no means new or exclusive with the 


\section{Compelling Chords}

author. All he has done is to put in language, which you follow with joy and satisfaction, the very things you have thought for years, but had never undertaken to communicate to others. Possibly you may never have tried to do so. Perhaps you questioned your own powers. Perchance you figured that there were not enough people in the world who care for a dark path through a pine forest, for instance, to warrant you in trying to say anything about it to anybody else. You just kept on at your job in some countingroom, store, law office or factory, wearing out soul and good shoe leathertrying to pile up cash enough to buy something that would probably fail to bring you the long-anticipated pleasure by the time you were able to obtain it-and yet all the time the picture of that woodland trail could not be altogether banished. And some day, some night, you will fall in with some writer who has allowed himself 


\section{In Winter Quarters}

to think out loud on some such secretly cherished subject, and if he be just honest, frank and fearless in telling the truth, even at the risk of being called a "crank" or a sentimentalist, he will contribute something to the library that will be found genuine some day, and may be helpful through all the generations. Horace has been dead near two thousand years, and the prophets longer than that, but they still walk up and down the world clad in immortality. There were prizefighters and money-changers also in their time. I don't happen to remember any of their names, however. Do you?

Many months-of-moons ago the boy who had made the big $\mathrm{O}$ wildcats in his books became part of an office equipment. The other furniture in the little room consisted of a chair, a desk, many books and a hoe now transformed into a lead pencil. It was just a case of plain, everyday grinding, and 


\section{Compelling Chords}

for years he toiled tediously, sometimes painfully, through days of depression and discouragement that sometimes threatened to overcome his resistance. There were many hours when his mind wandered from his work to an old wood-lot where a figurefour rabbit-trap used to be set in the snow on clear, cold, moonlit winter nights.

Just how many miles of manuscript of a more or less technical character came from his pencil point he has never taken the trouble to calculate. The main thing is that it somehow found a market, bringing in enough bacon to enable a few families to keep the wolves away from the doors. But ever on his ears fell the call of the quail along the cornfield fence. He was still "seeing things," and it was now well for him he could. Otherwise he might not have been able to keep on, for there are tragedies to be faced along this Via Sacra of the work-a-day 


\section{In Winter Quarters}

world; and he who can get inspiration from stones, and find good fairies hidden within the covers of certain books, has something at least to draw against in his day of spiritual need.

And one night he found and read "Walden," and after that the road to Dumbiedykes was clear. The backlogs of an open fire gave out the smoke and flame in which he saw and renewed acquaintanceship with every boy and bird and bush and berry he had ever known, and Vega's wireless message never failed. Thus came about one friendship based on letters.

I am so fond of Thoreau, just because of what he did for me, that I once made a pilgrimage of a thousand miles to pass a few hours in his company within the sacred groves that still skirt Walden's shore. Needless to say, I missed not other society. His spirit spoke from every pebble at the water's edge, from moss and fern and wild birdnote, from every nodding tree and 


\section{Compelling Chords}

narrow winding trail. True, a Fitchburg railway train was rumbling somewhere in the distance, and on the Concord road an automobile's honk was heard instead of cries of loons on Walden waves; but these were the only discordant notes. Otherwise peace primeval!

As usual with me, I did not find myself following the tourist crowd at Concord. The dear old town with its great elms, its battle-ground, its monuments and inspiring Colonial memories, is properly visited annually by a great many good Americans. "Its groves, its streams, its houses, are haunted by undying memories, and its hillsides and hollows are made holy by the dust that is covered by their turf." A native told me that 400,000 visitors had passed through the place last year. $\mathrm{He}$ might as well have said 4,000 or $4,000,000$, so far as my credulity was concerned. There is no lack of enterprise upon the part of historical so- 


\section{In Winter Quarters}

cieties in Massachusetts towns. They have done a wonderful work. Bronze tablets everywhere abound. In fact, they sometimes supply so many details-after the fashion of the old churchyard epitaphs-that at Concord I fully expected every time I turned around to find the spot well marked where Ebenezer Dow once sat or Prudence Prentice knitted. Just where Major Buttrick ate his breakfast the morning of the fight the tourist may never know. I was much more interested in the condition of the pine trees at the old Manse, and that big chestnut now flourishing in Emerson's front yard.

French's "Minute Man" will of course forever stand as the type of the stiff-necked generation that lived in the old town dozing there in the New England hills in April, I776, under the peace-abiding name of Concord. If there has ever been any ruction in which the Concordians did not loyally 


\section{Compelling Chords}

and pugnaciously participate I believe it has escaped being recorded. Thoreau certainly fired shots into the artificiality of modern life that were heard just as far as those of the embattled farmers, and yet you will find fifty tourists standing around where two or three Britishers were killed to where you will see one making for Walden Pond.

Apparently the average visitor knows more of Emerson and Hawthorne and Louisa Alcott than of the author of "Life in the Woods." I am not unappreciative, I hope, of their great contributions to our literature, but I like Thoreau best, just as I enjoy the swamp maples and water willows at Concord bridge better than the man-built arch that spans the dark waters of the tiny river. How the old "nullifier of civilization," the "halfcollege graduate, half-Algonquin" would have resented the gasoline invasion of those quiet sylvan scenes! [151] 


\section{In Winter Quarters}

Speedometers are frequently overworked on the winding roadways that are the pride of the New England of today, and I could not help but wonder what Paul Revere would think of my ride from Harvard Square through Lexington as compared with one he took on horseback on a certain memorable midnight. Cord-and-rubber hoofs are the kind that now do all the hurrying down the village streets. Another thing that would surely rouse the ire of my old friend is the way in which he has been dressed up in recent years by Houghton-Mifflin. I have Lowell and Longfellow and Emerson and Holmes in really nice full-calf bindings, and in an evil moment added a set of Thoreau in the same good garb, for which outrage upon his simple taste I humbly beg his pardon. Plain cloth is dressy enough for "The Maine Woods," but muskrat, mink or beaver skin would surely be a lot more becoming to the dear old tramp.

$$
\text { [152] }
$$




\section{Compelling Chords}

Thoreau was to me as cooling water to a thirsty wanderer in a desert of hot sands; as a breeze from across green meadows stealing like a benediction into a stifling prison cell; as the call of wild-fowl flying high above the busy haunts of men. I loved the good old Indian from the first. I love him still, and shall walk with him till the last.

While upon the subject of books, I held one in my hand the other day inside a fireproof vault, where many literary treasures are in storage, valued at $\$ 15,000$. I have no quarrel with the fads and fancies of the ancient and honorable guild of rare book collectors, but I do desire to file my protest against a fashion that runs mad over Boswell, Lamb and Browning, Shelley, Keats and Byron, Trollope, Thackeray and Dickens, Robert Louis Stevenson, Thos. Hardy and Oscar Wilde-in brief John Bulliana-and yet has no room upon its shelves for either classi- 


\section{In Winter Quarters}

cal, French, Italian or American literary triumphs.

I am not yet quite a collector. There is I am perfectly well aware in me moderate possibilities of one. I began collecting rare books for pot-boiling purposes long ago. I borrowed \$I,000 to buy some annotated sets that later proved a gold mine throughout an editorial apprenticeship. These were works of reference upon a more or less technical subject, and possessed no literary value. They have some of my own notes in them now, but I doubt if the whole lot would bring twenty per cent of what they cost more than thirty years ago. They have served their purpose along with a lot of bound manuscripts, long since consigned to the rubbish heap. But down in Philadelphia the other day-the city that has streets named for all sorts of beautiful trees, with no trees on themI saw in Rosenbach's famous stock various "association" books that are 


\section{Compelling Chords}

quoted at high prices. "Association" books and "Presentation" copies are held in greater veneration by your collector "fan" than first editions. An "Association" book may be one that derives its special value from the fact that it once belonged to some lion of the literary world. It may not be of any possible interest of itself, and it may be in an uncertain state of preservation, but if Wordsworth once owned it, and after writing his name in it, gave it away to his second cousin's great aunt or something like that, it may cost you $\$ 600$ to place it on your own book-shelves. You can buy Thackeray's old school algebra, if you want it, for $\$ 500$. You can get the last presentation copy Shelley made of "Prometheus Unbound" - first edition-for $\$ 5,000$. What the next to the last one the poet gave away may be worth deponent knoweth not.

Far be it from me, however, to disparage such evidences of interest in 


\section{In Winter Quarters}

the work and in the goods and chattels of the shining lights of English literature. Wealthy men may make a lot worse use of their money. There is a set of Shakespeare I would not mind owning, but for a little matter of $\$ 35,000$, standing in front of it. But when I asked what was on sale of special interest relating to Thoreau and Longfellow, there was a vacuum. I might give the price of a Ford for something that was dear to the hearts of the authors of "Walden" and "Evangeline." By the way, there is a little burial-ground near the corner of Spruce and Ninth Streets in the city of Penn, where it is said that the hero and heroine of the poet's plaintive Acadian love song lie side by side-the site being near that of the old alms-house where Evangeline found and nursed the long-lost Gabriel. They say that Longfellow and Hawthorne were together when the original Evangeline story was first brought to their notice, 
and that one wanted it for a poem and the other for a prose romance, Hawthorne yielding the privilege of treating it to Longfellow. Personally, and with all due respect to the writer of "The Scarlet Letter," I am very glad he did, if for no other reason than the opening stanza. Do you love majestic organ chords rising and falling through a great cathedral's heights and breadths? Do you know the voice of the wind roaring through the tops of woodland giants? Then read and hear the music of the lines beginning:

"This is the forest primeval!"

I inherited a few precious things; only a few, but none more prized than an autographed copy of William Edgar Marshall's fine big etching of the author of "Evangeline" and "Hiawatha," the portrait bordered by scenes illustrating episodes from various poems, and I rarely ever hear the clock that stands close by strike twelve 


\section{In Winter Quarters}

at night without standing in spirit on "The Bridge" trying to cast stray troubles off into the sea-ward current that flows forever underneath.

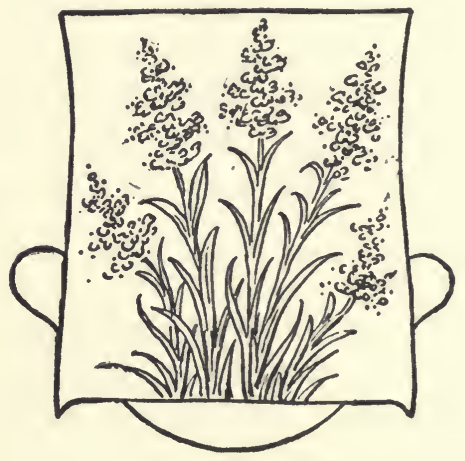

[158] 


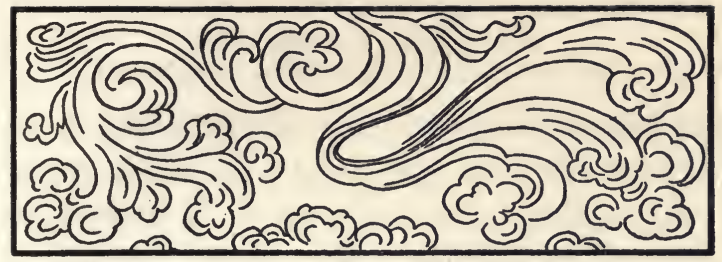

\section{XI \\ Eight Bells}

7 HE ship's clock on the book1 shelves by the door has chimed in admirably this evening with the booming of the surf beating heavily against the shore-line beyond the willows and the elms, and an old London edition of Capt. Cook's South Sea voyages has also fitted in well with the big lake's voice. It was for just such occasions that I desired the ship clock's congenial company. It will soon sound the eight bells that will announce a wintry midnight, and the barometer by its side explains the bellowing uproar on the waterfront.

The boy who was always seeing things in dumb walls and all sorts of 


\section{In Winter Quarters}

unheard-of places has since discovered that when in the mood he can with just a little adventitious aid summon for his own enjoyment and entertainment great picture galleries, through which he can wander at will for hours and forget that he is really alone. Incidental reference has already been made to the power in this: respect of certain photographs and etchings that form a part of the furnishing of the bookroom. These make their appeal through the eye; but his mind responds even more readily and more completely to suggestions coming in the form of sound waves.

It is plain to be seen that this habit of projecting one's self out into space, wherever the sound or the picture or the book may suggest, has its manifest advantages. It is more comfortable and less expensive, for instance, stretched out on a good old davenport, to sail the seas with Fenimore Cooper, Clark Russell, Jack London or Con[ I60] 
rad, here in Lincoln Park West, than actually to be aboard, and it doesn't take many accessories to outfit such a voyage. The stage is simply set. The weather man supplies a dark and stormy night, Lake Michigan the wash of waves, the ship's clock the actual striking of the nautical hours, a rattling story of blue water in your hand the necessary action; and with a vivid imagination of your own contrivanceyou are soon off-shore and far away, and best of all you will get back in time to sleep soundly in your own home cabin. Moreover, you do not have to make any hurried runs for the deck-rail, at the demand of a rebellious interior. I am not always disturbed by the rolling and pitching of the ship; still I know enough of mal de mer to appreciate the feelings of the negro soldier en route to France who, when asked if he did not want to see a passing ship, remarked, without getting off his back: "No, sah! Ah don't [16I] 


\section{In Winter Quarters}

want to see no ship! What ah wants to see is ah tree!" And there are no tips to the stewards, no customs officers or cabbies to hold you up at the dock.

Thoreau tells us of the nonsense of wanting to travel into distant climes for changes of air and temperature, pointing out that if you live anywhere in the temperate zones all you have to do to get any kind of climate you like is just to sit down and wait for it, and it will come along in due course. That is of course only a quiet $\mathrm{jab}$ at the fickleness of our weather conditions, and a reminder of the terrific extremes of heat and cold to which we are each calendar year subjected; but it is worth thinking about. And so with traveling. That can easily be managed at home.

There is a tiny French clock out there in the drawing-room. I do not have to get tickets and passports to visit Versailles. I have only to shut off the lights save those of the crystal chandelier, seat myself in one of those

[162] 


\section{Eight Bells}

old Bergeres, look at "The Return of Lafayette," close my eyes and wait for the silvery tinkle of that little bell, and voila! la belle Marie! Or Richelieu! The romance of the courts of France! Gay silks and powdered wigs! Jewels and perfumes rare! Old lace and roses!

Way down the back hall, encased in heavy mahogany, another timepiece, armed with thought-compelling chimes, stands up against the wall, and hammers away of Westminster! London bridge! The Tower! High Holborn! The Savoy or Piccadilly Circus! Hand me that old copy of Ainsworth's "Windsor Castle," bring my dressing gown and slippers, and with the deeptoned music of those imprisoned tubes of heavy brass, I shall soon be standing by Herne's haunted oak waiting for the spectral huntsman and the legendary hounds to start their thrilling midnight chase along the moonlit glades! And Anne Boleyn flirts gaily on her frivolous way! 


\section{In Winter Quarters}

There is the same steady, highpitched humming in the wind tonight I heard one wild day on the Mersey, when, it seemed to me, the shipping of half the world was riding at anchor in a gusty gale that was tearing its savage way up Channel to the granite docks of Liverpool. Tom Allan of the White Star Line could tell you of it, were he here. Like corks upon Niagara's brink, like the old Olivette in the choppy seas of the straits of Florida, like drunken dancers on a swinging floor, all sorts of craft of high and low degree were pitching, struggling, rising, falling, floundering, whirling, diving in one mad billowy salt-spray minuet. Night was coming on as we boarded the lighter that was to fight her way to the Cymric's side. A half hour of life, real life, ensued. Danger obviously lurked for the unwary passenger or sailor on that rolling flood, but there was something in it all that stirred the blood and steadied the nerves of men of [164] 


\section{Eight Bells}

Anglo-Saxon birth. And presently the great liner was discovered through the mists and spume lying in mid-channel motionless! Not a tremor shook that huge wall as the tender tossed and staggered at respectful distance to avoid a crash. Big hawsers thrown and turned were quickly taut, and as quickly torn away. "On with the dance," the sea nymphs sang, and four hundred tugs and smacks and coastwise ships obeyed. Alone, amidst the roar of wind and wave, the Cymric rode at peace. Once on her solid decks we knew the meaning of steadfastness and calm in troubled waters.

No! of course all can't be Cymrics. There are waters that giant liners may not safely navigate. But I have known some human Cymrics. A few only. One or two maybe. And to them I would trust my all; and by them I would swear in any sea. Even in midAtlantic with fire smouldering in the cargo in the great ship's hold, my faith 


\section{In Winter Quarters}

in her was unimpaired, and, sure enough, at the appointed hour Nantucket shoals were safely passed.

That one sharp stroke at this time o' night means 12:30, but I must finish this cigar. We once spent a half-hour in a small boat off Gibraltar, looking for another liner in a real honest-to-goodness fog. The sea was calm enough that afternoon, but the oarsmen certainly did look like typical throat-slitting pirates of the erstwhile famous Barbary Coast variety, and Billy knew at once that we were to be robbed and murdered out there all alone with those two swarthy brutes, and our bodies duly pickled in good Mediterranean brine. After paddling aimlessly around for what seemed an hour the deep call of the steamer was finally heard through the vapory banks, and the moustachioed boatmen had so little conception of their own real character-as drawn by one of their passengers-as to soon swing up alongside 


\section{Eight Bells}

a ship just weighing anchor for the Bay of Naples; and at break of day the sun rose gloriously behind Vesuvius.

I don't see why Bulwer-Lytton and a thousand other gifted travelers haven't done fuller justice to the Neapolitan coast. Marion Crawford lived long enough in Italy to have written even better than he did. And artists in droves have sketched all the way down from Sorrento to the Salernian Gulf, but quite in vain. There are some things I suppose that can only be seen and felt - not communicated. Doubtless there are men who would prefer a seat in Congress or the Cabinet to one at the Capuchini, but they could do more good to their souls, if not to their country, by serving a term on Amalfi's heights. If you would know the poverty of all the diamonds and the sapphires in this world go study that shimmering sea from the ancient monastery's walls.

Out there in front of our window in [167] 


\section{In Winter Quarters}

the blackness where the two main driveways meet, electric lamps are showing bright red danger globes, contrasting sharply with the soft white glowing lines that mark the winding of the boulevards amongst the trees. Two bells have just struck, and I can plainly hear the pounding of heavy waves, spouting like geysers as the sea wall's line is reached. We are off the Irish coast! About midnight a Cunarder, inward bound, had discharged her mails, and proceeded on her way. If you have not steamed up this coast on a moonless night, and have not seen the spectacular flashing of varicolored lights as headland after headland, one after another, is reached hour after hour, you have missed something worth sitting up on deck to see. You can sleep when you go ashore next day. And meantime as the passing panorama slowly dissolves itself into the mist you will translate "The Coastwise Lights of England" understandingly. [ 168] 
Was it Emerson who wrote of disliking the sea, because it seemed to him emblematic only of death? I love it; and see in its depths, and hear in its voices, life everlasting and infinity. I like everything about it, from the porpoises that play about the ploughing isteamer's bow to the pelicans that wing their unmolested way around Useppa's Isle.

There is a peculiar fascination about any old port that serves as a base for a fishing fleet. The stories that could be told by the docks of Gloucester were certainly not exhausted in "Captains Courageous." And one can conceive of nothing more impressive than that annual mid-summer ceremony there in memory of the many who have sailed away for "the banks" from the quaint old town never to return. Flowers strewn upon the ebbing tide bear sea-ward the message which, let us hope, is somewhere received and understood. The bell that warns of [ 169] 


\section{In Winter Quarters}

the reef of Norman's Woe still tolls when the fogs come in. And far to the South the keeper of Minot's Ledge answers the warning signals of Thatcher's Island and Cape Anne as darkness settles down upon a dangerous coast. And through all the generations old Mother Anne, steadfast and immutable as the rock beneath, mocks the Atlantic surge, and marks the coming and the going of the Gloucester fisher-folk. One does not need to possess any great divining power to catch her rugged profile as she lies there in the jagged rocks. Nearby is "Finisterre." There may be lovelier spots somewhere along this coast. There are charming country homes far back from the sea I knowinland-where hills and vales and streams and forest beauty all invite; but at Land's End the ocean adds to all of these its own inimitable wonders, new each day. Here, where the flowers and seaweed meet, a hammock is [ 170] 


\section{Eight Bells}

swaying in the August breeze. It will make you both happy and hungry. I know because I have tried it, and while dozing there until George announces dinner I have dreamed.

A sheltered sunken garden by the sea Where Flora and the sun-god met one day

To deck stone walls and granite gray

With roses rare and columbine;

A scene as fair as Iris-tinted morn.

Pan plays his pipes 'midst leafy bowers

Throughout long dreamy summer hours,

And ever, from remotest ocean caves,

Old Triton leaps and hoarsely winds his farresounding horn.

And here within this charmed seclusion deep

Sacred to all the household gods who keep

Their steadfast watch by night, by day,

O'er happiness and love and sweet content,

A gentle spirit dwells!

And if you seek and find the path

That leads you rightly to her shrine

You'll sense the fragrance of the Lotus-flower

That blossoms there,-

And if your luck's as good as mine,

And garden gods don't frown,

You may be asked to stop and dine.

[171 ] 



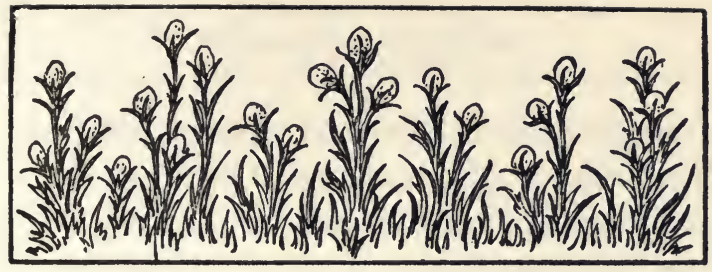

\section{XII}

Speaking of Rocks

$\mathrm{N}$ hoeing you sometimes strike a I stone. I always went after these. Firstly, to get them out of the way of the rootlets of the growing plants, and secondly to examine the rock itself, always hoping to find something interesting; something that looked as if it might have had a history. I have always been attracted by natural objects that I thought might tell great tales had they the power of speech. But in the gardens of my youth I do not remember ever finding more than one arrowhead, and no rocks of special interest except a few that showed curious forms that I now know were due to the grinding power of glaciers. 


\section{In Winter Quarters}

Out there in the cabinet, in the gallery, where you may see a quaint mixture of odds and ends from the four winds, you may find two discolored pieces of marble that a tourist once brought from Rome. The full extent of the crimes that have been committed by Cook's crowds will probably never be fully known. I was told one day in Concord that if Ralph Waldo Emerson's house had not been closed to strangers a few years ago there would by this time be nothing whatever left of either furnishings or foundations save memories. But getting back to lithological lore, I am now the custodian of a bit of the mosaic floor that was trod, once on a time, by the gay patrician guests of Cæsar Augustus, in an age when old Falernian, from all accounts, flowed quite as freely as the waters of the Tiber. At any rate, this bit of pavement was really picked up in the ruins of the emperor's palace, still visited annually 
by those who love the land of the ilex and the vine. Some of the scenes that this particular stone has looked upon if pictured here might possibly bar this little book from modern mails. The other is clearly a fragment of a cornice, and we know for a fact that it certainly looked down upon still earlier generations; because I saw it rescued from dirt and debris piled up by laborers excavating with pick and shovel, under the direction of learned antiquarians, in the lowest levels reached in recent times in the exploration of the Roman Forum. It was probably never seen therefore by either Cato or Cataline. It is beautifully carved, carrying a delicately chiseled Grecian design that may be seen today on any structure built on strictly classic lines. And if you have just a little of the gift of "seeing things," and will place it by your side as you read your Virgil, you will easily grasp the fact that this marble fragment 


\section{In Winter Quarters}

is endowed with truly magic power.

We think we are far advanced in all that pertains to our physical and spiritual well being, as compared with the ancients, but I see no evidence to support any such contention. It's a long trail from Babylon to Berlin, but the hanging gardens and fountains, the roses of Sharon and myrtles that grew about the walls of the one, certainly made it quite as desirable a place of residence, even under Nebuchadnezzar, as was the German capital under William Hohenzollern. We still turn to the Greece that was for our highest inspirations in fine art, and to pre-historic Egypt in the hope of solving secrets that died with the Pharaohs. Rome borrowed from them both, and we in turn gaze with amazement upon the luxuries revealed by the Baths of Caracalla, and delight to copy mural decorations preserved for us by the ashes of centuries in exquisite Pompeian interiors. The walls of Jeri- 
cho have fallen, but they built sewers and aqueducts better in the days of Claudius Maximus than we do under Gompers. No, they had no ocean cables nor any form of fast transportation by land, sea or air. They thought it enough to concentrate their energies upon the highest possible development of their own home-lands, and not dissipate energy as we do in scattering our interests and activities all over the habitable globe. Greece was all the world to the Greeks, and Rome and Carthage only fell after vainly attempting to extend themselves too far. At. least that is what I am told by my marble fragments every time I handle them.

The earth is nothing more or less than a great big rock surfaced with a little of its own disintegrated substance and decayed animal and vegetable matter, and populated now, as aeons ago, by certain self-satisfied insects, reptiles, birds, "bipeds without [ 177] 


\section{In Winter Quarters}

feathers" and quadrupeds, differing in type only, but not in habits, from the myriapods, trilobites, spoon-billed dinosaurs, and cave men of Cretacean, Eocenic or other early geologic ages. And Mars or some other distant belligerent is still throwing rocks our way. One of these, hurled by some solar Hercules at the state of Iowa many years ago, burned its flaming path overhead one winter night still well remembered. Afterwards I once watched the proving of a giant gun at Indian Head on the Potomac, and the roar of the great shells, as they tore their way through the air towards a distant bend in the river-like the muffled rumble of a heavy freight train on a long piece of trestle work-was not nearly so loud as the disturbance made by this monster meteor in its flight through our aero-sphere. This particular missile fired from some stellar Big Bertha, after frightening one-half the people 
of the state, buried itself in the earth, and was soon afterwards acquired by the State University.

I don't like to follow either geology or astronomy too far. They both lead you to the edge of a precipice so sheer and so enveloped in the clouds of mystery that you dare not look into the unfathomed depths without growing groggy. I prefer to take the sea as I see it at Sorrento, the cedar as it grows on the cliffs of Monterey, the pine tree as it stands erect on lofty Appalachian heights, the rose as it blooms in Baltimore, the corn as it wears its silk and tassels on the prairies of Illinois, the cattle as they graze on old Kentucky's hills, the cricket as it chirps now on my hearth at Dumbiedykes, the men and women who may be our guests when lamps are lighted right here in Chicago in this year of our Lord 1920, the stars as they rise and shine in obedience to some law I know not of, and cannot understand- 


\section{In Winter Quarters}

all just as they are, without asking "whence?" Or "whither?"

I can interest myself more or less in stratified rocks. They do not suggest hell fires and brimstone, as do their igneous brethren. In fact, I cannot look at those hardened laval products of unthinkable heat, thrown carelessly about as they have been by some unthinkable power, without shuddering at the terrors they inspire. I can stand for studying coquina or any other cemented sediment that reveals the fauna or the flora of a bygone age, but basalt and obsidian speak of dynamite.

Fossiliferous limestones are wonderful, if you care anything about your ancestry. Most of us here in America know our mother's maiden name, and some of us could tell you the given name of the paternal grandfather. A few may know where their great grandparents lived, or are said to have come from. A select few have [180] 


\section{Speaking of Rocks}

had their pedigrees traced as far as possible. Most of these researches have been conducted by females wishing admission to the D. A. R. That. is perhaps one good thing these doughty Daughters have done for us. But for that many a potential suffragette would never have known for sure whether she had a great-great-grand-parent or not. Just why this study of genealogy should develop among females such a bellicose disposition is, however, not so apparent. If you have ever seen the Daughter delegates in action in the convention staged annually at the National Capital you would understand this reference.

Of course along the Atlantic seaboard you hear always of "the old families," as if your family is or could be by any possibility any "older" than mine or that of the bumble bee sipping sweets from the royal-purple monk's hood blooming on the garden wall. The only difference is that some have [ $18 \mathrm{I}$ ] 


\section{In Winter Quarters}

kept track of their ancestry, and many have not cared enough about the matter to even inquire as to who was really responsible. No family is of course any better than it is. It is not a question of the names of the ancestors, but of their personality, and unfortunately genealogy commonly fails to supply sufficient information as to the amount and quality of gray matter or refinement, or mental and physical endowment generally to render it of any value to the student of scientific breeding or heredity.

We keep tab on our cows with much more intelligence. If the pedigree registry tells you exactly how much milk each female ancestress has yielded for generations past, you have a record of performance you can build upon with confidence. And if it appears from the books that the paternal ancestors have been distinguished winners at the shows, there is a useful chart to shape one's course by. In [182] 


\section{Speaking of Rocks}

stock breeding we know fairly well "where we are at" in this reproduction work, but with humans the eugenic proposition languishes. Hence we need expect no race of poets nor philosophers; not even a breed of pugilists with protruding chins. Just a grand pot-pourri of anything and everything that has gone before in one mad mixture blended "for better or for worse!"

Now, if we only had some way of handing ourselves down in good gray limestone garb for the information of future generations, men might make better progress in their own development. We know exactly how a Devonian Hipparionyx proximus looked, but you couldn't reconstruct accurately so comparatively recent a human product as say Alexander the Great to save your life; saying nothing about your own great-uncle and his wife.

After all, what does it matter? It makes little difference to me now or [183] 


\section{In Winter Quarters}

hereafter, so far as I can see, whether old Henry weighed I 80 pounds or 120 ; whether he was tall or short; whether dear old Patsy was blonde or brunette, slight or stout, or whether they were married on the Rappahannock or in the Shenandoah Valley. The sun will rise just the same tomorrow morning. No information as to how Adam and Eve looked is now obtainable. All we know is a little something about their dress, their diet and their immediate descendants, and what we know of some of the latter, such as Cain, Judas Iscariot, Nero and Trotsky, tends somewhat to frost any budding pride of human ancestry.

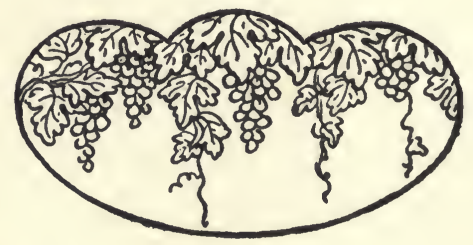

[184] 



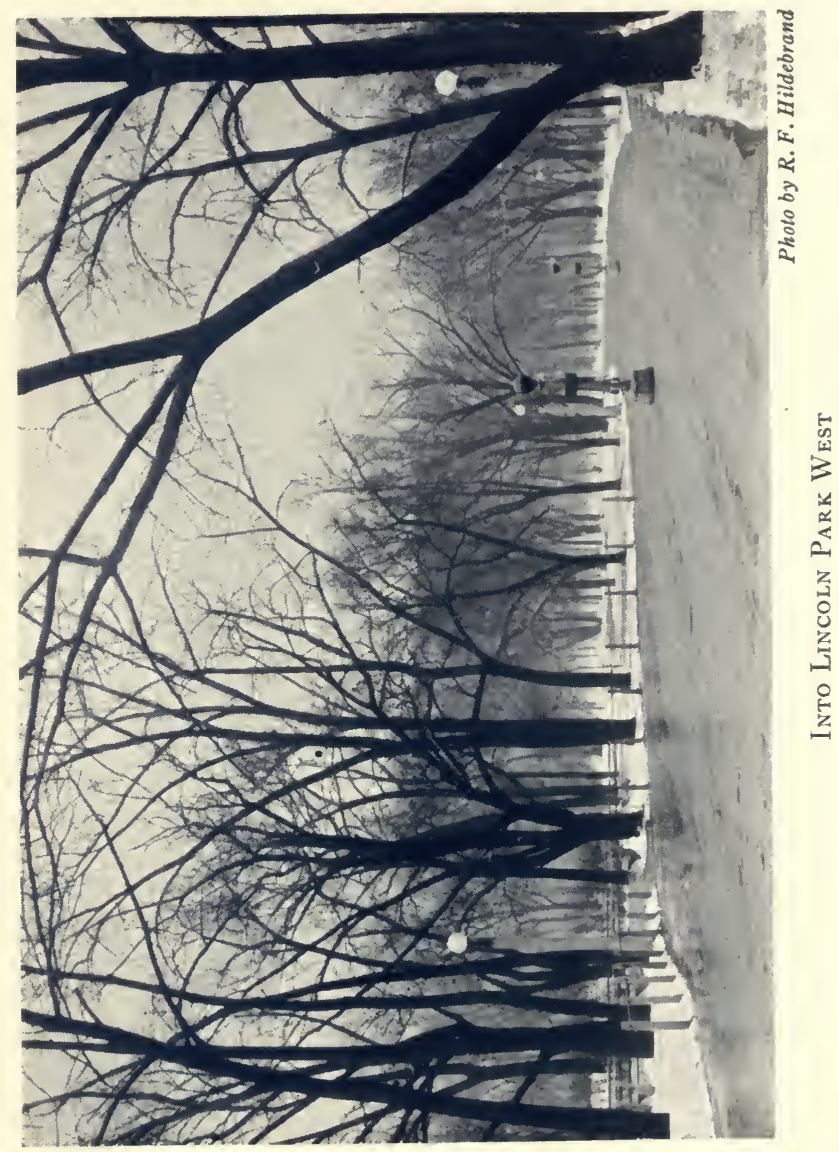




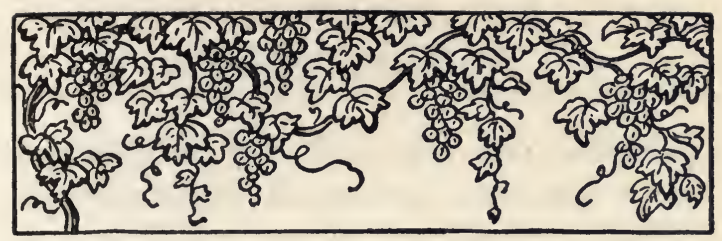

\section{XIII \\ One Way Out}

4 VEN hoes are entitled to an occa1 sional rest. Anyone whose fingers are blistered as a result of gripping the handle too tightly and too continuously will approve that sentiment. There are of course some people who are in no danger of doing themselves bodily injury through overwork. Such folk commonly make excellent fishermen. Successful angling is a pursuit calling for unlimited patience and congenital antipathy to hoes. It is not to this class therefore that this warning is specially addressed.

We all know persons who are by nature either ambitious to rise to the limit of their capacity in the world for [ 185 ] 


\section{In Winter Quarters}

personal reasons, or in order that they may become generous providers for others. Many of these unfortunately act upon the principle that all time spent in play is wasted, insisting, in the face of the universal experience, in riding their respective hobbies straight into hospitals. I have personal knowledge of the case of one, who after hoeing a row some thirty years long, with infrequent stops, finally found himself one day with hypodermic needles loaded with strychnine in his arms, and a trained nurse trailing his dragging steps. Needless to add, his hoe then had one long extended rest. It is again in commission, nominally at least, but is not now worked overtime.

That unrivaled painter, piper and poet of the wayside, woods and skies, king of all the Romanys living or dead, to whom I have already paid my homage, aided and abetted more or less by such people as Hesiod and [ 186 ] 


\section{One Way Out}

Horace, Columella and Cato, Burns and Burroughs, and various other esteemed brethren of the Oxygen Club, had often urged this man with the hoe to hang it up in the tool-house once in a while, and take to the woods, and he finally did; but so firmly fixed had the hoeing habit become that no sooner had he builded his little shack among the oaks than he began looking around for something he could cultivate. When the fever for work was upon him he had only to adapt Aladdin's little trick to his own particular needs; just rub the handle of the hoe with a forefinger and thumb bearing the calloused scars of service, and a field for its use would instantly reveal itself. Then down in a corner he would go, and you would likely see or hear little of him for the rest of that day or week.

Mrs. Burns has recorded the fact that Robert was not fit to live with during periods when he was actively engaged in composition. At such times 


\section{In Winter Quarters}

he was nervous, preoccupied, irritable and absolutely impossible, from the standpoint of conventional society. Had he played bridge, and danced well and often, I suppose she would have called him a dear, but had he done so during the summer that proved to be big with fate for the literary world it would not have been so well for Scotland. In fact, in that event the greatest poem of its type in any tongue, "The Cotter's Saturday Night," would never have been delivered. The poet was only seeing things as others also saw them, but he differed from all the rest in that he put upon himself, for the everlasting benefit of his fellowmen, the heavy burden of painting vividly and at great personal sacrifice of himself the immortal pictures that were so clear to him in the field and firelight! And while thus engaged he was of course a moody recluse! Such is the world's impatience, even with those who may be serving it best. I [ 188] 


\section{One Way Out}

suppose Beau Brummels serve some useful purpose. Maybe lap dogs do also. I never quite got the great idea myself, but let us "judge not." There can be absolutely no disputing over matters involving either taste or religion. We all like the bright lights sometimes, but one can find better companions occasionally in the sand dunes. Luckily for Scotland and the human race, Robert Burns had a greater fondness for a furrow in the field, and for the bonnie banks of Ayr, than for Leicester Square. Feast and the world feasts with you. Think and you think alone.

Scotland has perhaps given the world more in proportion to its area, and in proportion to its habitable acreage, than any other country. We can forgive oatmeal, Carlyle and Rob Roy Macgregor in the light of Burns and Barclay of Ury, Scott and Amos Cruickshank, Robert Louis Stevenson and William McCombie. The Scotch [189] 


\section{In Winter Quarters}

are not only the best farmers in the world, but the best golfers. In fact, they claim to have originated golf, as well as Galloways. And speaking of hanging up the hoe now and then, and of the Scots-and incidentally getting back to our muttons-in the interest of a depleted vitality, I have now for some few years past at intervals laid aside the governor's implement of soil culture, and its hexagonal No. 2 successor-bearing Eberhard Faber's brand-long enough to try to work my passage, amidst many difficulties, and with a different class of instruments, around a quarter-section of rolling grassland lying just in front of Dumbiedykes.

Long practice and a stroke easily acquired when one starts early enough in life, and follows the game up continuously for a number of years, had once made a country-bred lad fairly expert in destroying rag-weeds and cockleburs with one clean-cut swing of 


\section{One Way Out}

a keen-edged scythe. In fact, he often hears yet, when pushing a pencil in the town jail called his office, the music of the whetstone flying swiftly back and forth along the curving blade, and sees the golden rod, sweet clover and big broad burdocks going down before a rhythmic swaying under August suns. Unfortunately, however, this proficiency in that ancient and honorable game did not seem to help much when, in the first dash for the open air, blue sky and the companionship of meadow larks and other interesting people to be met with around good golf links, he resolved to resume partial touch with the soil of which he was so fond-and very little of which he owned-by buying a driver, brassey, cleek, mid-iron, mashie, putter, bag and balls, and a suit of "knickers;" the customary equipment, in other words, of those who take up as a means of relaxation the time-honored Scottish sport. 


\section{In Winter Quarters}

It was a Scotchman, in fact, who inveigled me into this-one John Clay. Some of you ranchmen and Stock Yard people and bankers and red foxes will perhaps have heard of him before, for he has been a very familiar figure, for lo! these many years, wherever round-ups, livestock conventions and packing-houses abound in this country. Also wherever border sportsmen meet along the Teviot or the Tweed to give poor Reynard chase. John could beat almost anyone when it was a little matter of shrewd use of grass on the Belle Fourche range. And Tom Wilson or Edward Swift or Mr. Forgan will tell you candidly he is "canny" in the realm of high finance. Moreover, any fox-hunter between the Cheviots and the Hills of Lammermoor will have tall stories of how he used to ride to hounds, rain or shine, from Monday morning until Saturday night.

But he can't play good golf. I know he can't play good golf because I have [192] 


\section{One Way Out}

often played with him myself, and once in a long time can bring him in one "down," and anybody that I can finish "up" on at a game of golf is no real golfer. Anyhow Clay started me. In fact, it may as well be recorded here as anywhere else that he is really the person who urged the building of the little cottage in the country that has now sheltered me for some seventeen consecutive summers under the name his sister gave it.

Now golf looks easy. It is for men who have a good burr under their tongue, and were caught before full maturity; but the average American business man who tackles it figures much more prominently in the list of those who contribute to the upkeep of the greens and lockers than he does in the roster of first-flighters in tournaments where one is expected to hit the ball. As a contributing member of a country club he is a pronounced success. As a golfer he ruins more turf 


\section{In Winter Quarters}

on the tees and through the fairways every Saturday during the summer months than a greenskeeper can renew in a month of painstaking replacement. Just the same he gets his money's worth with the biggest interest rate upon it of any investment he ever makes.

You see it is like this: You take a wooden club modeled on the lines of the old-fashioned "shinny" stick, a small white ball that is more sensitive than a drop of quick-silver on a hardwood floor, and you are to drive it two or three hundred yards straight down the line of play toward a goal objective-a tiny cup imbedded somewhere in supposedly velvety grass upon a putting green-but you probably will not. Rather you will look up too quickly and "top" or "slice" or "pull" the ball into a sand-trap, a stream of water, tall weeds or clover, brush or gravel pit, conveniently placed to catch dubbed shots. Then after looking for 


\section{One Way Out}

your ball a half-hour or so you may find it; and if you be stout of arm and find a niblick in your bag you may, if you have good luck, be able to chop the wayward pill back onto the lot where it belongs. You will then have to take another type of iron-and with devilish ingenuity the Scotch have originated more breeds of these than they have of sheep and cattleand try to make progress towards the flag that marks the hole for which you are supposed to be headed. By and by you will reach the "green." But the cup into which your ball has now to be "holed" is not half big enough. It should of course approximate the size of a full-grown wash-tub, but it doesn't. They say the cup is four inches wide. I don't believe it!

Now if you manage to get your own ball safely stowed away at last, in say seven strokes, counting from your first endeavor on the teeing ground, and Clay has taken eight, you have won 


\section{In Winter Quarters}

that hole from him. See? And so on for the whole eighteen. The only trouble with John is that they probably started him plowing instead of golfing when a wee braw lad at Wedderlie.

Meantime, however, you will have tramped six miles, with your feet on good old Mother Earth. The blue jays and the bob-o-links have been making sport of you all the while. Maybe your mind was on them part of the time instead of upon your game. Maybe the oat harvest or the waving cornfields over there beyond the hedge have meant as much to you as the winning of a match. Maybe the bluegrass and the grove, or that distant line of wooded hills, have claimed some share of your attention. Maybe the doffing of starched linen has made you altogether comfortable for the time being. Maybe all of a sudden you have realized that for three hours you have not thought of LaSalle Street or the [196] 


\section{One Way Out}

bank balance. And when you've done, and had your shower, you may find that somehow some of the cobwebs that were in your brain when you left town have been lost somewhere out there on the breezy links. And if you can't afford a real country place of your own you may say, with some of the rest of us, that golf after all is just another name for good medicine-not merely a trifling pastime for "the idle rich." Maybe it is a real blessing to the man of moderate means who has to work with his head inside brick walls, and has discovered in this good old outdoor sport one route by which he can travel back for a few brief hours at least to the soil from whence he, like all the other bugs, originally sprang.

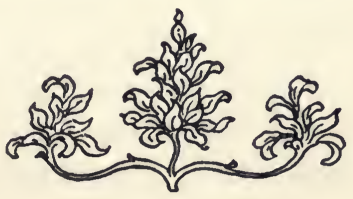





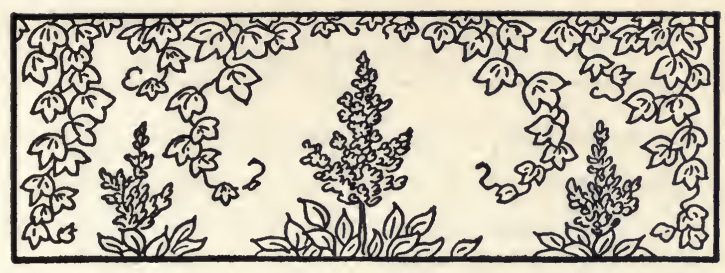

\section{XIV}

\section{As $Y e$ Hoe so Shall Ye Reap}

\section{HIS Christmas neither toys nor 1 sleds named "Snow Bird" came} my way, but from somewhere a copy of a book you may see there next to "Walden" and "Steep Trails." It is "The Spell of the Yukon" by Robert W. Service. It is Kiplingesque, intensely human, and there are times when its pulsing verse may suit one's mood better than any of its shelfmates.

"I wanted the gold and I sought it;

I scrabbled and mucked like a slave.

Was it famine or scurvy-I fought it;

I hurled my youth into a grave.

I wanted the gold and I got it;

Came out with a fortune last fall;

Yet somehow life's not what I thought it, And somehow the gold isn't all." 


\section{In Winter Quarters}

Men hunt their respective will-o'the-wisps in many other places than along the sands of the Yukon, only to learn at last that if these have been pursued at the price of the infinitely greater things of life, failure shall be written at the chapter's end.

We probably get about what is coming to us in this world, and with most of us that isn't much if measured by customary standards. The trouble is that only about one in ten million has had the luck to be endowed with the ability to make a big worldly mark for himself. Most of us may be fairly represented by small dots scattered along on either side of a horizontal line that we may call the dead level of mediocrity. These pin-heads are numbered in the millions, and as you look above or below this median line you will note that the dots that represent the rest of the brethren grow fewer and fewer until, both at the top and at the bottom, you will observe the isolated [200] 


\section{As Ye Hoe so Shall Ye Reap}

points that stand for absolute imbecility in the lower depths and dazzling brilliancy in the upper realms. All this you will find diagramed and discussed in Francis Galton's "Hereditary Genius." That distinguished savant will tell you that a Napoleon or a Shakespeare performs his apparently superhuman tasks with just as little effort as you and I manage our infinitely smaller undertakings; the difference being one of natural capacity is therefore fundamental.

The great mind is created, not made. If you have it, you have it. That is all there is to it. And you yourself are entitled to no credit whatsoever as an individual for being the mere custodian of something that can neither be bought, stolen nor acquired by study, thought or any other human process. And, on the other hand, if you have not been born into that sparsely settled zone where the truly great appear, you are not going to get very far in that [ 201 ] 


\section{In Winter Quarters}

direction, even if you hitch your own apple-cart to Aldebaran.

While this is undoubtedly true as respects the mountain peaks of human achievement; while a mind of exceptional power is only now and then given to some fortunate recipient, the fact remains that the average person rises or falls, within certain limits, above or below the middle line, substantially according to his own efforts and deserts. When I speak of brilliant worldly success, I refer not at all to the mere ownership of property. Possession of gold proves little or nothing, so far as real worth is concerned. It all depends upon how it was obtained. If by inheritance, by common highway robbery in some commercial guise, by stumbling upon a ledge of gold-bearing quartz, by beating some other fellow out of a valuable invention; or by guessing shrewdly in Wall Street, it may bring the limelight and liveries that attract the gaping crowd, but not 


\section{As $Y e$ Hoe so Shall Ye Reap}

admission into honestly conducted galleries, of fame. On the other hand, the mere fact that a man has means is not necessarily proof that he is a rascal. There are instances where men of brains, men of high ideals and aspirations, men of genius, have actually held their own in the great riot of money-getting and maintained themselves in accordance with the conventional requirements of contemporary civilization. These are apt to be exceptions, however.

Assuming that you are an average individual, it is well to grasp the fact that while you will probably never be able to live in the sun-because those few who do are born to that exalted place-you will very likely harvest in the long run just about according as you ply your hoe. And do not worry as to whether you are born great or not. If you are you will soon find yourself sailing easily away from your fellows. You can't keep genius down. 


\section{In Winter Quarters}

It was born to fly, and is self-starting. But along this great crowded highway of the average, you will find it very necessary to hoe; to hoe early and to hoe late; to hoe persistently, and to hoe not just on the surface, but deep. There is too much competition-except in the Napoleon-Shakespeare classto admit of any other course if you expect to keep above the line even a few degrees. Loaf too much and you are left. Hang up your hoe too frequently, and you will go without potatoes.

The great thing is to do whatever is given you to do in the very best manner possible. I don't care if it is blacking some other fellow's shoes. If you make so good a job of it that it compels the attention of the owner, you can rest assured that he will recognize the fact, and argue from it that since you have done even so small a thing as that so well you are more than likely to do something more important better than 


\section{As $Y e$ Hoe so Shall Ye Reap}

the average, and your promotion will not stop until you strike a level where you can no longer excel, and there you find your probable limit. Nobody knows just where that is to be found until he has tried, and tried hard. We all have our limitations-even the tenmillionth man-but it is up to each to test things out for himself.

The idea that rgetting along in the world is altogether a matter of "pull" is of course a convenient excuse for one's own failure to progress. One man may hoe just as hard as his neighbor, and not get on nearly so fast nor harvest anything like so good a crop; and he may be just as honest, just as faithful and in some cases apparently more deserving than his mate. And he and his friends are apt to talk of the "luck" of the other fellow, and talk of favoritism. Well, it is, in one sense; but if so it is probably nothing more than the favor extended to the one by the gods and denied by them, for some inex[ 205] 


\section{In Winter Quarters}

plicable reason, to the other. One hoes true to the line, never makes a miscue, every stroke counts. He knows the soil, and how to handle it. $\mathrm{He}$ knows weeds from the plants he is cultivating. He works with his head as well as with his hands. And of course he reaps a bigger crop than the fellow who has not been given equal mentality.

Some may say that is a hard pronouncement; that it is condemning offhand and in advance a majority perhaps of the human race to be in a way mere "hewers of wood and drawers of water"; that we are born into a servitude from which there is no rising; that such a doctrine is fatal to effort, and dispels ambition. If by that you interpret this as holding that we are all substantially what we are born to be, and that we can only make minor changes in our destinies, I stand by the record. But don't forget that the "hewer of wood" you talk about [ 206 ] 


\section{As $Y e$ Hoe so Shall Ye Reap}

usually has an infinitely better chance for happiness than had Hannibal, and that the "drawer of water" does not by any means necessarily need your sympathies. On the contrary. More than half our troubles grow out of an utter misconception as to who is to be really pitied, who envied.

If you want to hoe for gold dollars and nothing else, do it. I shall not. I want coin enough to satisfy the grocer, tailor and landlord, but I have not hoed and will not hoe only toward the mint. I never was good at figures, anyhow. My marks in arithmetic when a school boy were apt to be disgraceful. Fractions and finance have never interested me half as much as finches, and it takes a good mathematician to make a hatful of money; one who loves the inexorable algebraic equation. When I went higher up, however, the case was different, for geometry made its great appeal to the heights and depths that deal with 


\section{In Winter Quarters}

mountain mysteries and the journeys of the moons of Jupiter. And, if I remember correctly, at Cornell I actually came through my "spherical trig" exam. with the one "cum laude" mark of my brief course of study at that institution. I am inclined to think that I had more real interest in those days in the 'varsity crew and the boathouse on the Inlet than in most of my studies on the glorious hill that still looks down upon Cayuga's waves of blue.

I am surely kin to the African in one respect at least, in that I shall never accumulate a fortune, own a grand house, or show place in the country, because for me sufficient unto the day is the bacon and the meal. That is of course a somewhat extravagant statement. I do differ in certain degree from the Senegambians. I hoe until I can see enough bread and meat in sight for tomorrow and maybe the next day, before I go philandering with Perseus 


\section{As Ye Hoe so Shall Ye Reap}

or some other wanderer in the great voids that lie between the bank vault and the blue one overhead. The difficulty is that it has taken me so long to dig up supplies enough to last until day after tomorrow that I am having to file a very strenuous plea for an extension of the time limit in order that I may enjoy for a reasonable period the harvest sweets of human existence. And so if this little book has any message at all for those now headed down the trail it must be just this:

Hoe! But in working this garden into which you and I and all of us were born do not put off too long the planting and cultivation of a few roses as well as rhubarb; spireas as well as spinach. I know you will produce more beans if you give up all your ground to them than if a little space is devoted to dahlias, and that it may look foolish to erect a martin house instead of building another chicken 


\section{In Winter Quarters}

coop. Another concrete pig trough may pay bigger cash dividends than a birdbath standing underneath green overhanging boughs. You can grow corn right up to the front doorsteps if you want to filch from the ground every bushel of which your total acreage is capable. You can buy the adjoining farm-which you may not need half so badly as a modern bathroom-and extend your proprietorship in a way that may gratify your personal vanity or pride. You may do a lot of things that leave out of consideration all but the material things of this world, only to learn, too late perhaps, that a fountain placid, plashing always somewhere in the quiet sanctuary of your inner self, fed from the deep still waters of the Everlasting Source, might have added something you have somehow missed.

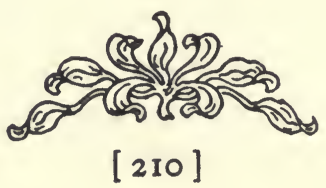




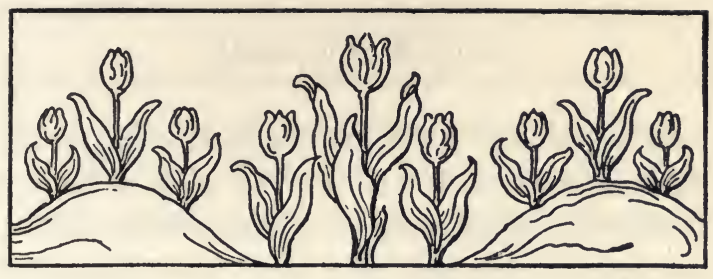

\section{$\mathrm{XV}$ \\ "Fair and Warmer"}

WHERE the ice first formed along the edges of the park lagoon last November there also may you look for it first to yield when winter's grip begins to break in March. The bonds are to be relaxed in gentler fashion than they were forged. The fogs and rain are gradually luring back the life that has so long been ruthlessly repressed. "Thaw with his gentle persuasion is more powerful than Thor with his hammer. The one melts; the other breaks in pieces."

This morning there is open water where yesterday the ice still held. Geese are bucking the northern line with flying-wedge. The catkins on the 


\section{In Winter Quarters}

willows are turning yellow; the dogwood crimson. A misty haze hangs over all, and faint suggestions of color - grays, greens and browns-may be seen around the tree tops. In the park the gardeners are raking the dead leaves out of the belts of shrubbery where the bulbs have long been waiting for that vernal ceremony. They have already heard the summons, and each is now prepared to show what he has found down there beneath the surface. Where do they get it all? How does one find red, another yellow? Or both? Some scientist will tell you, but that is one thing I do not care to know all about. It would take half the pleasure out of it. Let them keep some of their secrets. Their petals are enough to satisfy reasonable souls.

The gates are opening slowly. They are not to be thrown outward with one great thrust by an unseen power, but quietly, even noiselessly, as the grass emerges from the softening earth. The 
first robin makes no effort to announce to you his arrival. He has probably been somewhere round-about for several days before you see him: In the vicinity of our great cold-storage reservoir, Lake Michigan, he usually comes too soon for his own comfort. $\mathrm{He}$ braves the searching winds; and although the bare ground as yet yields up no food he stands firmly by his enterprise.

It has now been many weeks since those bulbs were buried where last summer's flowers had bloomed. Since then there has been little time to think of them. Matters of more consequence, from conventional standpoints, have claimed attention. It is only during idle hours that one may be permitted to deal with such comparatively trivial things as tulips. But one tires of this everlasting wrestling with the problems of how dollars and reputations among men may best be coined. Some of those who may have followed me 


\section{In Winter Quarters}

thus far will understand that all this discursive chat about a lot of things in general, and nothing much in particular, does not constitute the beginning and the ending of the real day's work. Rather let it be known that such attempts at diversion from the daily grind represent only an effort to relax the strain under which we all labor in greater or less degree as we seek to perform each his allotted part.

I have given perhaps my share of time and thought to other things than bees and birds and bulbs and books, but now and then I just have to throw the window open wide, and take a good look at the waving trees and the distant horizon, or run the risk of "blowing up." And the fact that some other people are similarly situated is the only possible justification for a working-man writing or reading a little something now and then that makes no pretense to being anything more than the chaff, 
that is in reality own cousin to the solid grain. With which animadversion let us remark that the man doesn't live- - r if he does he isn't fit to livewho is wholly insensible to the elevating influence of the first warm days of spring - the days on which, according to Thoreau, "all men's sins are forgiven." Peach blossoms will soon be strewing their pinkness 'round about the cabin doors of Dixieland, and this side the Ohio the plums and thorns prepare to fling their fragrance far and wide.

The first real signal for a thousand forms of both animal and vegetable life is the earliest muffled thunder-clap. Frogs leap and croak for joy, and violets wake. "Hello! Hello! Hello!" is heard from every hill and dale. "Here we all are again!" comes from the singing brooks and swelling buds. High on the topmost branch a mocking bird can scarcely find ecstatic notes enough to run the gamut of the love [215] 


\section{In Winter Quarters}

songs of the air; and the rainbow frames the picture of a world re-born.

You may trust the bees to find the first pollen on the earliest willow's tassels. They are tired of last year's honey, and are keen for newer sweets. They may be idiots about some things, but they are wiser than Solomon in others. There is one fool thing a bee will do. Before we left Dumbiedykes last fall we had to move a hive to a more sheltered position; just across the little lawn from the quince hedge to an angle in the south wall of the house. It was an unseasonably warm day in late October, following a cold wet week. Some of the inmates had evidently gone out foraging among the few straggling remnants of the floral year, for after their box had been carried to a spot not more than forty feet away from where it had stood all summer they were utterly unable to find it. They made no attempt to do so. They just buzzed aimlessly around 
the spot that had been their home, and were as completely lost as if the hive had been shipped to Halifax. They were still hanging around the old familiar spot as a stormy night came on, and doubtless starved to death within easy sight of safety. I am satisfied that it would have been the same if the hive had been moved but ten feet instead of forty. Instinct they have, plenty of it, but it is truly blind.

Today I took my own way back to where another "hive" has stood for lo! these many years, and found it as of yore. For it had not been moved. $\mathrm{Had}$ it been missing from its old accustomed place amidst the trees, had I found bare ground where once the sweets of life had been, I had been lost more hopelessly perhaps than were the homeless bees.

Yes, I confess I am attached to Dumbiedykes, poor as it is. Maybe I am like the tree that overhangs the roof, in some respects. This oak is 


\section{In Winter Quarters}

rooted firmly to that particular spot, even though its surroundings may seem mean and unattractive to those who look for spacious lawns and gardens.

This, our roof-tree, is fated never to attain heights reached by many of its kind. It has not the elm's graceful habit of yielding easily to inevitable conditions. Unlike the willow down there by the stream, it bends and bows not always when perhaps it should. My burr oak has not Sequoian majesty. Still it has shown a certain amount of determination or it would long ago have succumbed to the discouragements of the hard clay soil through which it has had to make such way as it has found. It is not so symmetrically developed as it might be. It has a good side, and one that is sadly deficient. The products of its trunkthe branches it has put out into the little world by which it is surroundedare more or less erratic and eccentric in character. Still at divers times they 
have served to help some certain humble folk along their way. I know of several to whom it has at least extended shelter. But they go away. It is, in short, just one of many of its kind growing near perhaps the median line of oaken excellence, loving the summer sun, and rejoicing in the visits of its friends.

Storms have passed over it, and it shows the scars. Whatever it is or is not, however, it is mine, and if thou art my friend and stand with me sometime beneath its wide-extended boughs, I pray thee do not fault it over much. It is the best I have. It has made the best use possible of such advantages as it has enjoyed, and has clearly had its full share of adversity to contend with since the day it began its career in the midst of surroundings not of its own making. And I love it for the struggle it has made, and for such headway as it has attained. It protects our western [219] 


\section{In Winter Quarters}

windows from the fervid suns. It has thrown broad branches over the roof under which we sleep; and the raindrops pattering from its leaves upon the shingles overhead are as a loving mother's lullaby.

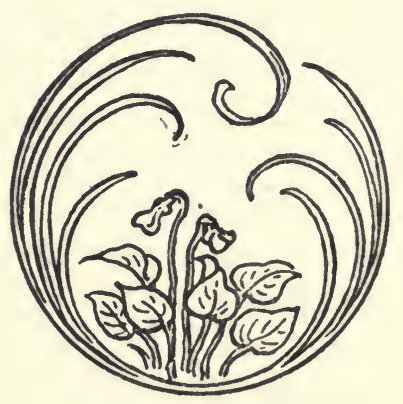

[220] 

PRINTED BY R. R. DONNELLEY AND SONS COMPANY AT THE

LAKESIDE PRESS, CHICAGO, ILL. 

THIS BOOK IS DUE ON THE LAST DATE STAMPED BELOW 
